Australian

National

University

Crawford School of Public Policy

\title{
CAMA
}

Centre for Applied Macroeconomic Analysis

\section{Can This Time Be Different? Policy Options in Times of Rising Debt}

\section{CAMA Working Paper 23/2020 March 2020}

\section{M.Ayhan Kose}

World Bank

Brookings Institution

CEPR

Centre for Applied Macroeconomic Analysis, ANU

Peter S. O. Nagle

World Bank

Franziska L. Ohnsorge

World Bank

CEPR

Centre for Applied Macroeconomic Analysis, ANU

Naotaka Sugawara

World Bank 


\section{Abstract}

Episodes of debt accumulation have been a recurrent feature of the global economy over the past fifty years. Since 2010, emerging and developing economies have experienced another wave of historically large and rapid debt accumulation. Similar past debt buildups have often ended in widespread financial crises in these economies. This paper examines the factors that are likely to determine the outcome of the most recent debt wave, and considers policy options to help reduce the likelihood that it ends again in widespread crises. It reports two main results. First, the rapid increase in debt has made emerging and developing economies more vulnerable to shifts in market sentiment, notwithstanding historically low global interest rates. Second, policy options are available to lower the likelihood of financial crises, and to help manage the adverse impacts of crises when they do occur. These include sound debt management, strong monetary and fiscal frameworks, and robust bank supervision and regulation. The postcrisis debt buildup has coincided with a period of subdued growth as well as the emergence of non-traditional creditors. As a result, policy priorities also need to ensure that debt is spent on productive purposes to improve growth prospects and that all debtrelated transactions are transparently reported.

\section{Keywords}

Financial crises, currency crises, debt crises, banking crises, public debt, private debt, external debt.

\section{JEL Classification}

E32, E62, F34, G01, H12, H63, N2O

\section{Address for correspondence:}

(E) cama.admin@anu.edu.au

ISSN 2206-0332

The Centre for Applied Macroeconomic Analysis in the Crawford School of Public Policy has been established to build strong links between professional macroeconomists. It provides a forum for quality macroeconomic research and discussion of policy issues between academia, government and the private sector.

The Crawford School of Public Policy is the Australian National University's public policy school, serving and influencing Australia, Asia and the Pacific through advanced policy research, graduate and executive education, and policy impact. 


\title{
Can This Time Be Different? Policy Options in Times of Rising Debt
}

\author{
M. Ayhan Kose, Peter S. O. Nagle, Franziska L. Ohnsorge, and Naotaka Sugawara*
}

This Version: March 2020

\begin{abstract}
Episodes of debt accumulation have been a recurrent feature of the global economy over the past fifty years. Since 2010, emerging and developing economies have experienced another wave of historically large and rapid debt accumulation. Similar past debt buildups have often ended in widespread financial crises in these economies. This paper examines the factors that are likely to determine the outcome of the most recent debt wave, and considers policy options to help reduce the likelihood that it ends again in widespread crises. It reports two main results. First, the rapid increase in debt has made emerging and developing economies more vulnerable to shifts in market sentiment, notwithstanding historically low global interest rates. Second, policy options are available to lower the likelihood of financial crises, and to help manage the adverse impacts of crises when they do occur. These include sound debt management, strong monetary and fiscal frameworks, and robust bank supervision and regulation. The post-crisis debt buildup has coincided with a period of subdued growth as well as the emergence of non-traditional creditors. As a result, policy priorities also need to ensure that debt is spent on productive purposes to improve growth prospects and that all debt-related transactions are transparently reported.
\end{abstract}

Keywords: Financial crises; currency crises; debt crises; banking crises; public debt; private debt; external debt.

JEL Codes: E32; E62; F34; G01; H12; H63; N20.

\footnotetext{
* Kose (World Bank, Brookings Institution, CEPR, and CAMA; akose@worldbank.org); Nagle (World Bank; pnagle@worldbank.org); Ohnsorge (World Bank, CEPR, and CAMA; fohnsorge@worldbank.org); and Sugawara (World Bank; nsugawara@worldbank.org). We are grateful to Carlos Arteta, Justin-Damien Guénette, Jongrim Ha, Alain Kabundi, Sergiy Kasyanenko, Patrick Kirby, Franz Ulrich Ruch, Sandy Lei Ye, Dana Vorisek, and Shu Yu for their contributions to background research, literature reviews, and comments. We would like to thank Eduardo Borensztein, Kevin Clinton, Antonio Fatas, Erik Feyen, Catiana Garcia Kilroy, Ugo Panizza, Fernanda Ruiz-Nunes, Anderson Caputo Silva, Christopher Towe, and Igor Esteban Zuccardi, as well as participants at seminars and institutions around the world for many useful suggestions and comments. We thank Shijie Shi and Jinxin Wu for excellent research assistance. The findings, interpretations, and conclusions expressed in this paper are those of the authors. They do not necessarily represent the views of the institutions they are affiliated with.
} 


\section{Introduction}

Episodes of debt accumulation have been a recurrent feature of the global economy over the past fifty years, in both advanced economies and emerging market and developing economies (EMDEs). Sometimes, these have been highly synchronized eventually turning into global waves of debt (Kose et al. 2020). These synchronized waves have typically ended in widespread financial crises. At other times, rapid debt buildups have been country-specific, but half of these country-specific debt buildups have also been associated with crises (Koh et al. 2020).

Since the global financial crisis, debt has risen rapidly to an all-time high of roughly 230 percent of global GDP in 2018 (Figure 1). The increase has been driven by EMDEs, whose total debt also reached a record-high of almost 170 percent of GDP in 2018, an increase of 54 percentage points of GDP since 2010. While China accounted for the bulk of this increase, specifically in private debt - in part due to its sheer size - the debt buildup was broad-based. In contrast, in advanced economies, total debt has remained near the record levels reached in the early aftermath of the global financial crisis, at about 265 percent of GDP in 2018.

The current environment of low interest rates, combined with subpar global growth, has led to a lively debate about the benefits and risks of further government debt accumulation to finance increased spending (Kose, Ohnsorge, and Sugawara 2020; World Bank 2019a). ${ }^{1}$ Although the focus of this debate has been mainly on advanced economies, it is also of critical importance for EMDEs. Borrowing can be beneficial for EMDEs, particularly in economies with substantial development challenges, if it is used to finance growthenhancing investments in areas such as infrastructure, health care, and education. Government debt accumulation can also be appropriate temporarily as part of countercyclical fiscal policy, to boost demand and activity in economic downturns.

However, particularly for EMDEs, high debt carries significant risks, since it makes them more vulnerable to external shocks (Kose, Ohnsorge, and Sugawara 2020). The rollover of debt can become increasingly difficult during periods of financial stress, potentially resulting in a crisis. High government debt can also limit the size and effectiveness of fiscal stimulus during downturns, and dampen long-term growth by weighing on productivity-enhancing private investment.

EMDEs have been navigating dangerous waters as the post-crisis debt buildup has coincided with multiple challenges for these economies. They have experienced a decade of repeated growth disappointments and are now confronted by weaker growth prospects in a fragile global economy (Kose and Ohnsorge 2019; World Bank 2020; Figure 2). In addition to their rapid debt buildup since the global financial crisis, these economies have accumulated other vulnerabilities, such as growing fiscal and current account deficits, and a compositional shift toward short-term external debt, which could amplify the impact of shocks.

\footnotetext{
${ }^{1}$ For example, Blanchard (2019), Blanchard and Summers (2019), Furman and Summers (2019), and Krugman (2019) argue for increased borrowing, whereas Auerbach, Gale, and Krupkin (2019), CRFB (2019), Mazza (2019), and Riedl (2019) caution against debt accumulation.
} 
Thus, despite current exceptionally low real interest rates, including at long maturities, rapid post-crisis debt accumulation could follow the historical pattern and eventually culminate in financial crises in EMDEs. Debt distress could be triggered by unexpected, sustained jumps in global interest rates or in risk premia. In a highly uncertain global environment, EMDEs face a wide range of risks, including the possibility of disruptions in advanced-economy financial markets, steep declines in commodity prices, increased trade tensions, and a sudden deterioration in corporate debt markets in China. If any of these risks were to materialize, they could lead to a sharp rise in global interest rates or risk premia or weakening growth and, in turn, trigger debt distress in EMDEs. Indeed, these risks were illustrated by the recent experiences of Argentina and Turkey, which witnessed sudden episodes of sharply rising borrowing costs and severe growth slowdowns.

Several factors are likely to shape the trajectory of the most recent debt buildup, including prospects for global interest rates and economic growth. Although EMDEs are not in full control of some of these factors, they would benefit from utilizing the lessons from their own experiences with debt accumulation to avoid the mistakes of the past. Against this backdrop, this paper addresses the following four questions. First, how does the post-crisis debt buildup compare with earlier ones? Second, how have earlier debt buildups been resolved? Third, which factors may shape the trajectory of debt in the next few years? Finally, what policy lessons do historical episodes of debt accumulation offer?

In the course of answering these questions, the paper makes three contributions to an already-rich policy debate. First, the paper discusses the likely evolution of the increase in global debt since the financial crisis from the perspective of EMDEs. It also considers the recent debate about the merits of debt accumulation in the current era of low interest rates. Previous work has mostly focused on the consequences of debt accumulation for advanced economies. Second, the paper offers a compilation of salient lessons about the consequences of debt accumulation building on earlier research on global and national episodes of debt accumulation (Koh et al. 2020; Kose et al. 2020). Third, the paper offers a comprehensive set of policy prescriptions that can help lower the likelihood of debtrelated financial crises and mitigate their effects when they materialize.

The paper presents the following findings.

First, the debt accumulation in EMDEs since 2010 stands out for its size and speed. Since 2010, EMDE debt has risen by almost 7 percentage points of GDP per year, on average. The debt buildup in China has accounted for the bulk of the average EMDE debt increase and was predominantly (more than four-fifths of the total debt buildup) in the private sector. Total debt has risen in about 80 percent of EMDEs and by at least 20 percentage points of GDP in just over one-third of EMDEs. to the previous three waves, when the buildup was concentrated in one of the two sectors.

Second, many EMDEs now also share a wide range of external and domestic vulnerabilities that have historically been associated with a higher likelihood of financial crises. In addition, EMDEs are confronted by a wide range of risks in an increasingly fragile global context and amid slowing growth. As a result, despite currently record-low global interest rates, stronger policy frameworks in some EMDEs, and a strengthened international safety net, the post-crisis debt accumulation could follow the historical pattern and result in financial crises. History shows the critical importance of policy choices in reducing the 
likelihood of the post-crisis debt buildup ending in crisis and, if crises were to take place, mitigating their impact.

Third, debt accumulation is unlikely to be benign unless it is well-spent to finance truly output-enhancing purposes and it is resilient (in terms of maturity, currency and creditor composition) to economic and financial market disruptions. This requires not only prudent government debt management but also robust financial system regulation and supervision and sound corporate governance. It is critical to respond effectively to external shocks especially when there are domestic vulnerabilities. Private debt can quickly turn into public debt during periods of financial stress. Once debt distress materializes, prompt resolution is critical to avoid a prolonged period of weak economic activity.

Fourth, although specific policy priorities depend on country circumstances, there are four broad strands of policy options that can help contain the risks associated with debt accumulation. Governments need to put in place mechanisms and institutions that help them strike the proper balance between the benefits and costs of additional debt, such as sound debt management and high debt transparency. The benefits of stability-oriented and resilient fiscal and monetary policy frameworks and exchange rate regimes cannot be overstated. Financial sector policies need to be designed to foster responsible private sector borrowing. This includes robust supervisory and regulatory systems as well as corporate and bank bankruptcy frameworks that allow prompt debt resolution to limit the damage from debt distress. Finally, it is essential to have strong corporate governance practices and effective bankruptcy and insolvency regimes.

The remainder of this paper is organized as follows. The next section discusses the factors that may determine the likely evolution of debt in light of the challenges confronting EMDEs. The subsequent section draws lessons from the analysis of global and national episodes of debt accumulation. This yields the policy options discussed in the following section. The paper concludes with a summary and suggests topics for future research.

\section{How does the post-crisis debt buildup compare with earlier episodes?}

Spurts of debt buildup are common in EMDEs. Since 1970, there have been about 520 national episodes of rapid debt accumulation in 100 EMDEs when debt rose by more than one standard deviation above its rolling trend (Koh et al. 2020). In 45 and 38 EMDEs, respectively, such government debt accumulation and private debt accumulation episodes were still underway in 2018. Debt buildups during such episodes have tended to be particularly pronounced in government debt. The median debt buildup from the beginning of the episode to peak debt has been twice as large for government debt (30 percentage points of GDP) as for private debt (15 percentage points of GDP). For comparison, between 2010 and 2018, government debt rose by 20 percentage points of GDP and private debt by 10 percentage points of GDP in the median EMDE that was in a rapid debt accumulation episode during this period.

When episodes of rapid debt accumulation coincide in many countries, they form global waves of debt. There have been four such waves of broad-based debt buildup in EMDEs since 1970. The first spanned the 1970s and 1980s, with borrowing by governments in Latin America and in low-income countries (LICs) in Sub-Saharan Africa (Sachs 1986). This wave saw a series of financial crises in the early 1980s. The second wave ran from 
1990 until the early 2000s as banks and corporations in East Asia and Pacific and governments in Europe and Central Asia borrowed heavily, and ended with a series of crises in these regions in 1997-2001 (Kawai, Newfarmer, and Schmukler 2005). The third wave was a runup in private sector borrowing in Europe and Central Asia, which ended when the global financial crisis disrupted bank financing in 2007-09 and tipped several economies into sharp recessions (Frank and Hesse 2009). The fourth wave (2010 onwards), in contrast, has covered all EMDE regions.

The three previous waves displayed several significant similarities. They all began during prolonged periods of very low real interest rates, and were often facilitated by changes in financial markets that contributed to rapid borrowing (Figure 3). The three past waves all ended with widespread financial crises and coincided with global recessions $(1982,1991$, and 2009) or downturns (1998 and 2001). These crises were often triggered by shocks that resulted in a sharp increase in borrowing cost stemming from either an increase in investor risk aversion and risk premiums or a tightening of monetary policy in advanced economies. These crises typically featured sudden stops of capital flows. They usually led not only to economic downturns and recessions but also to reforms designed to lower external vulnerabilities and strengthen policy frameworks (Kose and Ohnsorge 2019). In many EMDEs, inflation-targeting monetary policy frameworks and greater exchange rate flexibility were introduced, fiscal rules were adopted, and financial sector regulation and supervision were strengthened (Alfaro and Kanczuk 2016; BIS 2018; FSB 2018a).

These similarities notwithstanding, the waves differed in some fundamental dimensions. The financial instruments used for borrowing shifted over time as new instruments or financial actors emerged. The nature of EMDE borrowers on international financial markets has changed, with the private sector accounting for a growing share of borrowing through the first three waves. The severity of the economic damage done by the financial crises that ended the first three waves also varied across the waves, and across regions. Output losses were particularly large in the first wave, when the majority of debt accumulation was in the government sector and debt resolution was protracted.

The debt accumulation in EMDEs since 2010 has already been larger, faster, and more broad-based than in the previous three waves. Since 2010, EMDE debt has risen by almost 7 percentage points of GDP per year, on average (Nagle 2020). The debt buildup in China has accounted for the bulk of the average EMDE debt increase, was much faster than that in the third wave, and was predominantly (more than four-fifths of the total debt buildup) in the private sector. Whereas previous waves were considerably more pronounced in some regions than in others, the post-crisis debt buildup has been global, with total debt rising in about 80 percent of EMDEs and by at least 20 percentage points of GDP in just over one-third of EMDEs. Most national episodes of rapid debt accumulation since the global financial crisis have involved both government and private debt accumulation, in contrast to previous waves, when the buildup was concentrated in one of the two sectors.

In other aspects, the post-crisis debt buildup bears resemblances to earlier ones. Similar to its predecessors, interest rates have been very low during the post-crisis debt buildup, and search for yield has contributed to falling spreads for EMDEs. Some major changes in financial markets have again boosted borrowing: these include a rising role of regional 
banks, a growing appetite for local currency bonds, and increased demand for EMDE debt from the expanding shadow banking sector. As in earlier waves, vulnerabilities have mounted since the global financial crisis, with a shift to riskier debt instruments, including greater reliance on financial markets and non-Paris club bilateral lenders (particularly in LICs; Essl et al. 2019; Kose et al. 2020; Ruch 2019).

\section{How have past episodes of debt accumulation been resolved?}

About half of the national episodes of rapid debt accumulation were associated with a financial crisis, with sizeable economic costs in terms of permanent output and investment losses (Koh et al. 2020). Crises associated with rapid government debt buildups tended to feature larger output losses than crises associated with rapid private debt buildups.

While financial crises were often triggered by external shocks, such as sudden increases in global interest rates, during rapid debt accumulation episodes, domestic vulnerabilities often increased the likelihood of crises and amplified their adverse impact. Most countries where crises erupted suffered from unsustainable combinations of inadequate fiscal, monetary, or financial policies. Crises were more likely, and the economic distress they caused was more severe, in countries with higher external debt - especially short-termand lower levels of international reserves. When both government and private debt rose together - as they have since the global financial crisis - the likelihood of a currency crisis was higher than when government or private debt accumulated individually. When these national debt accumulation episodes combined into global waves of debt, they culminated in widespread financial crises that coincided with global recessions or downturns.

\section{The post-crisis buildup of debt: What next?}

The period since the global financial crisis has already included the euro area debt crisis and several EMDE currency crises. Capital flows to EMDEs have been volatile since 2010, with episodes of substantial outflows in 2013, 2015, and 2018. During these episodes, many EMDEs experienced large jumps in bond spreads and significant currency depreciation against the U.S. dollar. In 2018, the risks associated with elevated debt were illustrated by the experiences of Argentina and Turkey, which suffered sharp increases in borrowing costs and slowdowns in growth.

Although EMDEs have gone through periods of volatility over the past decade, they have not experienced widespread financial crises. The key question is whether the post-crisis debt buildup will at some point end in financial crises in many EMDEs, as all its predecessors eventually did, or whether such crises will be avoided perhaps because EMDEs have learned and applied their lessons from the past. A wide range of factors will determine the evolution of the latest global debt buildup and its consequences for EMDEs.

\subsection{Prolonged period of low interest rates}

Low borrowing costs incentivize countries to accumulate debt. For instance, an easing of U.S. financial conditions, a bellwether for global financial conditions, has typically accompanied an increase in capital flows to EMDEs (Feyen et al. 2015). But increased borrowing can also raise vulnerability to a future rebound in interest rates. Historically, rising global interest rates have been a key trigger for financial crises, as documented in 
many studies. ${ }^{2}$ EMDE borrowing costs tend to rise sharply during these episodes, and higher debt servicing costs can cause debt dynamics to deteriorate rapidly.

The current environment of low interest rates and persistently low inflation in advanced economies alleviates some risks associated with the post-crisis debt buildup. Policy interest rates in many advanced economies are near historical lows after major central banks recently reverted to an easing stance after winding down tightening cycles in 2018 . Moreover, monetary policy in advanced economies is likely to be accommodative for the foreseeable future as growth prospects and inflation expectations remain subdued (Figure 4). This is reflected in low policy interest rate expectations in 2020-22. In EMDEs, many of which face slowing demand growth, subdued prices for their commodity exports, and disinflationary pressures, policymakers may also cut policy rates further in the near term.

Structural headwinds also seem likely to keep real interest rates low in the longer term. Estimates of the neutral interest rate, the rate consistent with stable inflation and an economy operating at full capacity, have declined markedly across advanced economies over the past decades (Holston, Laubach, and Williams 2017). The structural factors responsible for this decline are likely to persist. These include slowing labor force growth, a product of population aging and declining birth rates; slowing productivity growth since the most recent peak in the late 1990s; and muted prospects for a productivity revival (Eggertsson, Mehrotra, and Robbins 2019; Fernald 2016; Gordon 2012). An increased demand for safe assets, driven in part by the quantitative easing by central banks in major advanced economies and decreased appetite for capital investments also seem likely to continue weighing on interest rates (Del Negro et al. 2017; Rachel and Summers 2019; Williams 2018).

Low global interest rates have encouraged an aggressive search for yield, bouts of large capital flows to EMDEs, and a sharp narrowing of bond spreads. Around one-quarter of sovereign and corporate bonds issued in advanced economies - and some euro denominated bonds issued by Poland and Hungary - currently trade at negative yields. ${ }^{3}$ Negative yields on advanced-economy debt already helped compress debt service burdens for EMDE borrowers and nudged debt toward a declining path in the future. Thus, interest payments on EMDE government debt fell from an average of 2.6 percent of GDP in 2000-07, to 1.6 percent of GDP in 2010-18, despite the increase in debt over that period.

The debate on the implications of low interest rates for additional debt accumulation has focused on advanced economies. ${ }^{4}$ Some have argued that advanced economies, especially

\footnotetext{
${ }^{2}$ See, for example, Claessens and Kose (2014), Frankel and Rose (1996), Kaminsky and Reinhart (2000, 2001), and Summers (2001) for the sources of financial crises.

${ }^{3}$ In the two EMDEs with recent negative yielding sovereign bond issuances, government, household and corporate debt have risen only moderately over the past decade. Spreads on emerging market debt both for corporate and sovereign bonds reached all-time lows in 2017, boosting borrowing. Average spreads on corporate bonds have fallen from pre-crisis levels for all EMDEs, including LICs, as well as for lower rated corporate bonds.

${ }^{4}$ Blanchard (2019), Blanchard and Summers (2019), Furman and Summers (2019), Krugman (2019), and Rachel and Summers (2019) discuss reasons for additional government spending financed by borrowing in advanced economies, and the United States in particular, whereas Alcidi and Gros (2019), Auerbach, Gale, and Krupkin (2019), CRFB (2019), Eichengreen (2019), Mazza (2019), Riedl (2019), Rogoff (2019), and Wyplosz (2019) caution against adding to debt, citing in particular the example of the United States.
} 
those that issue reserve currencies, should take advantage of low interest rates to borrow more to finance priority expenditures. Others have cautioned that high debt weighs on long-term growth, by increasing the risk of crises, limiting the scope for countercyclical fiscal stimulus, and dampening private investment.

For EMDEs, there are additional concerns about debt sustainability even during times of low global interest rates. First, financing costs may be low relative to GDP growth, but they may not be low enough to offset the sheer magnitude of borrowing (Kose, Ohnsorge and Sugawara 2020). Second, both interest rates and growth rates are highly volatile in EMDEs.

During 1990-2018, the interest rate-growth differential was negative in more than half (58 percent) of country-year pairs. ${ }^{5}$ However, even in about one-quarter of these instances, the differential was not large enough to offset the increase in debt from primary balances and maintain the government debt ratio on a stable or declining path. As a result, during 1990-2018, primary balances, long-term interest rates, and nominal GDP growth were such that debt was on a steadily rising trajectory in 43 percent of country-year pairs among 34 advanced economies and 50 percent of country-year pairs among 83 EMDEs (Figure 5).

In addition, the interest rate-growth rate differential is volatile in EMDEs. When borrowing costs rise, they rise more steeply in the average EMDE than in the average advanced economy; when growth slows, it slows more sharply in the average EMDE than in the average advanced economy. On average in those months during 1990-2018 when long-term interest rates increased, they rose by 0.3 percentage point in the average EMDEs, two-thirds more than the average advanced-economy. Similarly, when real GDP growth slowed from one year to the next during 1990-2018, it slowed by 3.2 percentage points in the average EMDE, compared with 2.5 percentage points in the average advanced economy. ${ }^{6}$

For these reasons, low or falling global interest rates provide no sure protection against financial crises for EMDEs. Indeed, half of all crises during episodes of rapid debt accumulation in 100 EMDEs since 1970 occurred in years when U.S. long-term (10-year) interest rates were falling and one-eighth occurred in years when U.S. long-term real interest rates were below 1 percent (as they have been since 2016).

\subsection{Weak growth prospects}

In addition to interest rates and fiscal positions, economic growth is another major determinant of debt sustainability. An important reason for rapid debt accumulation has been the sharp growth slowdown since 2010. EMDE growth slowed after 2010 to a trough of 4.1 percent in 2016 before a modest recovery took hold (Kose and Ohnsorge 2019). The

\footnotetext{
${ }^{5}$ Over the period 1990-2018, 53 percent of country-year pairs among 34 advanced economies and 62 percent of country-year pairs among 83 EMDEs had interest rates lower than growth. Over a longer, 200-year, horizon for a smaller sample of 55 mostly advanced economies, average interest rates have also been lower than average growth rates more often than not, but marginal borrowing costs rose steeply during crises (Mauro and Zhou 2019).

${ }^{6}$ When nominal GDP growth slowed in EMDEs, it slowed by more than 6 percentage points on average during 1990-2018, compared with less than 3 percentage points in advanced economies.
} 
growth slowdown during 2011-16 was broad-based (affecting more than three-fifths of EMDEs) and protracted. Amid this broad-based growth weakness, EMDEs have struggled to fully unwind fiscal and monetary stimulus implemented during the global financial crisis. This eroded EMDE fiscal positions and resulted in additional borrowing to maintain current spending levels.

During the current buildup of debt in EMDEs, potential growth has also declined, because of slower productivity growth as well as demographic change (Ruch 2019). Productivity growth has declined as investment growth has slowed, gains from factor reallocation have faded (including the migration of labor from agriculture to manufacturing and services), and growth in global value chains has moderated. Slower investment growth has tempered capital accumulation. Demographic trends have also become less favorable to growth, since the share of working age populations in EMDEs peaked around 2010.

Current trends in these fundamental drivers of potential growth suggest that it is likely to slow further over the next decade, to a pace about 0.5 percentage points lower than in 2013-17 (Kilic Celik, Kose, and Ohnsorge 2020; World Bank 2018a). For commodityexporting EMDEs - almost two-thirds of EMDEs - growth prospects will be further dimmed by the expected slowdown in commodity demand growth as major commodityconsuming emerging markets slow and mature (World Bank 2018b). The past decade has been marked by repeated growth disappointments. If these persist into the next decade, they could lead to growing concerns about debt sustainability, even in a world of low interest rates.

Moreover, during the current buildup of debt in EMDEs, there have been signs that debt has been used for "less efficient spending" rather than on productive investment in physical or human capital that could boost potential growth in EMDEs (IMF 2019a). Among commodity exporters, declining tax revenues following the commodity price plunge of 2014-16 widened fiscal deficits and raised debt despite lower investment (World Bank 2018b). Meanwhile, house prices have risen sharply in EMDEs, suggesting that some of the rise in private debt has contributed to asset bubbles.

\subsection{Mounting vulnerabilities}

In addition to the increase in debt seen by many EMDEs since 2010, these economies have also seen rising fiscal, corporate, and external vulnerabilities (Figures 6 and 7). These include lower international reserves, and larger shares of EMDEs with current account and fiscal deficits.

Although still above their 1980s and 1990s averages, international reserves relative to external debt have fallen since 2010 in more than two-thirds of EMDEs, and in onequarter it has more than halved. Current account deficits in EMDEs averaged 4.5 percent of GDP in 2018, compared with 3.1 percent of GDP in 2010. In 2018, 55 percent of EMDEs had weaker current account balances than in 2010; 76 percent ran current account deficits (compared with 69 percent in 2010); and 44 percent had current account deficits in excess of 5 percent of GDP.

An average cyclically-adjusted primary fiscal deficit of 0.6 percent of GDP in 2007 in EMDEs had widened to 0.9 percent of GDP by 2018. About one-half of EMDEs had a larger deficit in 2018 than in 2010. Commodity-exporting EMDEs experienced larger 
deteriorations in fiscal balances, on average, and were running the larger deficits than commodity importers.

There has also been a significant change in the composition of debt in EMDEs. In some EMDEs, the share of nonresident-held bonds in local currency bond markets has grown to more than 30 percent. In LICs, debt has been increasingly financed by non-concessional and private sources. This shift could generate new vulnerabilities. For example, increasing issuance of foreign-currency-denominated corporate debt has contributed to rising currency exposures and heightened the risks of financial distress in the corporate sector and the banking system in the event of a sharp U.S. dollar appreciation.

\subsection{What could make debt expensive?}

Debt sustainability in EMDEs could be threatened by a sudden increase in borrowing cost that could be driven by various factors. These include a normalization of monetary policy in advanced economies, disruptions in advanced-economy financial markets, commodity price shocks, trade tensions, a corporate debt event in China or a sovereign debt event in LICs, climate-related shocks, or domestic policy or political shocks.

First, although it seems unlikely in the foreseeable future, a return to monetary policy normalization in advanced economies could raise borrowing costs (Ruch 2019). If there was a rapid increase in policy interest rates, as happened at the start of the Latin American debt crisis, it could be accompanied by large currency depreciations in EMDEs that would sharply increase debt service burdens for foreign currency-denominated debt (Arteta et al. 2016). It would also be likely to trigger a turn in investor sentiment that would especially affect those EMDEs with large foreign participation in local bond markets, which in some economies now exceeds 30 percent of government bonds.

Second, disruptions in advanced-economy financial markets remain a possibility. The global financial crisis was marked by disruptions in advanced-economy financial markets which spilled over to some EMDEs, particularly those in Eastern Europe and Central Asia. Since then, a decade of tightening banking regulation has encouraged the emergence of maturity mismatches and credit risks among institutions in the non-bank financial system (IMF 2019b). Financial stress in non-bank financial institutions could quickly propagate to the rest of the financial system, owing to the interconnectedness between nonbanks and banks. Growing linkages between non-bank financial systems in advanced economies and EMDEs have increased both the likelihood and the potential magnitude of spillovers from distress in advanced-economy non-banks to EMDE bond markets and broader financial systems.

For example, leveraged loans - defined as loans to firms that are highly indebted, have high debt service costs relative to earnings, and are typically below investment gradehave become an increasingly important part of corporate debt in both advanced economies and EMDEs (BIS 2019). The outstanding stock of leveraged loans has doubled since the global financial crisis (BIS 2018).

Since most leveraged loans are denominated in U.S. dollars, tend to be at variable rates, and are often short term, they are highly vulnerable to rising financing costs. More than half of leveraged loans are packaged into collateralized loan obligations (CLOs), a form of asset-backed security with notable similarities to the collateralized debt obligations 
(CDOs) based on mortgage loans that played a key role in the global financial crisis. ${ }^{7}$ In search for yield, non-bank financial institutions such as pension funds and insurance companies have sought to invest in riskier and less liquid assets in order to meet their nominal return targets. Foreign portfolio investors and global mutual funds have also become more active in EMDE bond markets (IMF 2019b). This includes increasing their issuances of leveraged loans, which have risen significantly in every EMDE region, but especially in East Asia and Pacific.

Third, commodity price shocks would erode many EMDEs' ability to service debt. Many commodity-exporting EMDEs rely heavily on revenues from the resource sector to fund government expenditures and service sovereign debt (Correa and Sapriza 2014). As a result, commodity price shocks have periodically disrupted government finances and been a source of financial instability in EMDEs, culminating in some cases in sovereign debt default or other financial crises (Figure 8$).{ }^{8}$ Indeed, prior to World War II, commodity price booms often culminated in sovereign defaults in EMDEs (Reinhart and Rogoff 2014). The relationship weakened during the post-war period, but commodity price booms and associated terms of trade movements have remained a major predictor of financial and sovereign debt crises (Caballero 2003). In LICs, especially, commodity price shocks have often been associated with financial sector fragility and banking crises (Eberhart and Presbitero 2018; Kinda, Mlachila, and Ouedraogo 2016).

Fourth, an escalation of trade tensions could depress output in the short term as well as the medium term (Barattieri, Cacciatore, and Ghironi 2018). ${ }^{9}$ International trade has been a key engine of growth in EMDEs over the past two decades. By increasing investor uncertainty and triggering U.S. dollar appreciation, escalating trade tensions could also cause a significant tightening in global financial conditions (Dizioli and van Roye 2018). Heightened uncertainty could encourage capital flight into safe advanced-economy assets, potentially precipitating sudden stops in EMDEs. U.S. dollar appreciations would increase the real value of sovereign and corporate debt denominated in foreign currency and could trigger a retreat of EMDE lending by global banks (Bruno and Shin 2015). To the extent that EMDEs' trade is invoiced in U.S. dollars, bilateral depreciation could raise the price of tradeable goods and restrict inventory financing, disrupting global value chains. ${ }^{10}$

Fifth, the large corporate debt buildup in China since 2010 remains a vulnerability even if it has been primarily to domestic creditors. Its counterpart in the financial system could eventually reveal nonperforming loans and result in a growth slowdown in China. Concerns also remain about overcapacity in some industries resulting from the debt-fueled

\footnotetext{
${ }^{7}$ Both are based on an underlying pool of low-quality loans, structured in tranches of differing seniority based on exposure to credit losses, and are vulnerable to sudden increases in both the magnitude and correlation of losses. However, CLOs are less complex than CDOs, are not commonly used as collateral in repo transactions, and their impact on banks' direct exposures is better understood.

${ }^{8}$ Even in advanced economies, commodity price swings have sometimes triggered financial crises. For example, the financial crisis of 1837 in the United Kingdom was preceded by a sharp increase in commodity prices (Bordo, Dueker, and Wheelock 2003).

${ }^{9}$ In addition, EMDEs rely in part on the proceeds from trade taxation to meet spending needs and sovereign debt obligations (van Wijnbergen 1987).

${ }^{10}$ Boz, Gopinath, and Plagborg-Moller (2017) and Bruno, Kim, and Shin (2018) discuss the consequences of the critical role of dollar in international transactions.
} 
rapid investment growth of the past decade. ${ }^{11}$ Although it has recently declined, high corporate leverage, particularly in state-owned enterprises, has been associated with declining corporate profitability and financial performance (Molnar and Lu 2019; World Bank 2018b). In view of the size of China's economy, adverse spillovers to other EMDEs would be likely to be significant, including through portfolio reallocation among asset classes (Ahmed et al. 2019; World Bank 2016).

Sixth, LICs have accumulated debt rapidly and increasingly from non-concessional and less transparent sources of finance (Essl et al. 2019). These developments have increased LICs' vulnerability to financing shocks and to the revelation of previously undisclosed debt obligations. ${ }^{12}$ Transparency about contingent liabilities in LICs, such as those stemming from state-owned enterprise debt and public-private partnership transactions, as well as government asset holdings is also limited. These data limitations are especially acute for debt owed to commercial and non-Paris Club creditors. Poor data coverage can give rise to sudden increases in disclosed debt, for example when debt of loss-making stateowned enterprises migrates to the books of the central government. ${ }^{13}$

Seventh, for some EMDEs, risks related to climate change are substantial. Climate-related risks are particularly pronounced for economies where physical capital and infrastructure is located in high risk areas, and smaller EMDEs that rely heavily on climate-sensitive industries (such as agriculture and tourism) but have limited scope for economic diversification. The experience of several economies in LAC, in particular, shows that debt crises can be triggered by natural disasters. Furthermore, the move to a low-carbon economy could have a material effect for energy-exporting EMDEs. A shift away from the use of carbon-intensive fuels could leave the assets of fossil fuel companies, including stateowned companies, stranded by rules to curb climate change (Carney 2015). This could have critical implications for debt sustainability both at the firm and the country level.

To the extent that natural disasters are becoming more frequent and persistent as a result of climate change, they are likely to increase macroeconomic volatility and reduce longterm growth prospects, posing a growing risk to debt sustainability in vulnerable EMDEs (Nakatani 2019). EMDEs tend to adopt pro-cyclical policies in the aftermath of natural disasters, which may further deepen the macroeconomic costs of these events (Noy and Nualsri 2011). Political unrest after climate shocks or additional investment needed for climate adaptation may lift government borrowing cost, further increasing the likelihood of debt distress (Klomp 2015). Finally, extreme weather events can lead to a significant deterioration of fiscal and trade balances which in turn may trigger financial distress and debt crises. ${ }^{14}$

Finally, elevated debt increases an economy's vulnerability to domestic financing and political shocks even in an environment of benign global financing conditions. Domestic

\footnotetext{
${ }^{11}$ For details, see Maliszewski et al. (2016), Yu and Shen (2019), and Wang, Wan and Song (2018).

${ }^{12}$ For details, see Bova et al. (2016), Horn, Reinhart, and Trebesch (2019), and Lee and Bachmair (2019).

${ }^{13}$ For example, in Mozambique and the Republic of Congo, the revelation of unreported debt led to large upward revisions to official debt figures, which resulted in debt distress (IMF 2018a). Only a third of the 59 countries eligible for International Development Association borrowing report private sector external debt statistics (World Bank and IMF 2018).

${ }^{14}$ For details, see Acevedo (2016), Lee, Zhang, and Nguyen (2018), and Lis and Nickel (2010).
} 
financing shocks can trigger sharp increases in borrowing costs. These may include the sudden emergence of contingent government liabilities, including in state-owned enterprises or public-private partnerships. Policy surprises or sudden bouts of policy uncertainty can also fuel investor concerns about debt repayment causing a spike in borrowing costs.

Economies with unstable political regimes are more prone to financial crises and increased volatility in borrowing costs (Cuadra and Sapriza 2008; Yu 2016). Political instability and unrest often precede debt crises, particularly when a rapid buildup of government debt necessitates policy adjustments that have important distributional consequences (Andreasen, Sandleris, and Van der Ghote 2019). Conversely, political stability tends to be associated with a lower likelihood of sovereign default and quicker resolution of debt crises (Trebesch 2019; Van Rijckeghem and Weder 2009).

\subsection{Better policy frameworks}

Since the 1990s, policy frameworks in many EMDEs have become more resilient. The number of EMDEs with inflation-targeting monetary policy regimes and the number with fiscal rules have risen considerably since the late 1990s, macroprudential tools have been used more proactively and bankruptcy rights protections have been strengthened.

Monetary and exchange rate policy frameworks have improved. The number of EMDE with inflation targeting monetary policy regimes and flexible exchange rates has risen from only three and 11, respectively, in 1999 to close to 30 in each case in 2018 (Figure 9). Many EMDEs also improved the transparency of their central banks over this period, helping to anchor inflation expectations. With improvements in domestic monetary policy frameworks and the global decline in inflation, EMDEs have been able to bring inflation down from double-digits in the 1990s to about 3 percent in 2019 (Ha, Kose and Ohnsorge 2019).

Fiscal policy frameworks have strengthened. Fiscal rules have been adopted in more than 60 EMDEs. While the effectiveness of these rules-based policy frameworks has varied, they facilitated effective countercyclical responses by some of these economies during the last global recession, and could help buttress against future shocks (Alfaro and Kanczuk 2016).

Macroprudential policies have been used more activity. Since the global financial crisis, over two-thirds of EMDEs have tightened macroprudential rules - such as standards for bank capital, liquidity buffers, and loan-loss-provisioning - to contain risks from rapid private sector credit growth or house price growth (Cerutti, Claessens, and Laeven 2017). EMDEs have made efforts to contain risks from volatile capital flows through policies aimed at financial institutions, particularly restrictions on foreign currency exposures, reserve requirements on foreign funding, and liquidity-related measures (Ruch 2019). The overall effectiveness of these policies has depended on how they have interacted with macroeconomic and sector-specific policy measures (Bruno, Shim, and Shin 2017; Claessens 2015).

Since the 2009 global recession, some EMDEs have undertaken reforms to strengthen business climates (although reform momentum slowed after 2010) and reduce trade costs, which can strengthen long-term growth prospects. Recent reforms in bankruptcy 
procedures include the introduction of new bankruptcy laws in Egypt and India, the strengthening of secured creditors' rights in India, and the establishment of new restructuring mechanisms in Poland. Nevertheless, EMDE bankruptcy protection laws still lag international best practices, with creditors often experiencing long, costly, and weakly enforced debt recovery processes.

Since the global recession, there have been reforms to improve access to finance while strengthening financial supervision. Since 2009, several EMDEs that are FSB members have established national financial stability councils or committees along FSB guidelines (Brazil, China, India, Mexico, Russia, Turkey), and given their central banks new mandates to conduct macroprudential supervision (Indonesia, Russia, South Africa; FSB 2018b, 2019). Most of these EMDEs have made progress in implementing reforms, especially to meet Basel III capital and liquidity requirements and implement over-thecounter derivatives reforms (FSB 2018b). EMDEs that are also members of the Basel Committee on Banking Supervision, including Brazil, China, Russia, and South Africa, have put in place risk-based capital rules, liquidity coverage ratio regulations, and capital conservation buffers (BCBS 2019).

The crisis led to a rethinking of the role, benefits, and costs of financial and capital account liberalization, especially in light of the role played by cross-border capital flows in financial crises (Reinhart and Rogoff 2008; Ruch 2019). A consensus has emerged that capital flow management measures can play a legitimate role in promoting macroeconomic and financial stability (Koh and $\mathrm{Yu}$ 2019). Along these lines, Brail has reined in large capital flows, and China and India have continued their gradual pace of capital account opening.

Financial sector reforms developed at the global level since the crisis have also increased resilience (Arteta and Kasyanenko 2019; BIS 2018). The G20 global financial regulatory reform agenda has led to major financial reforms, including the international adoption of the Basel III capital and liquidity standards (FSB 2018a). Global financial safety nets have been expanded significantly, with the volume of resources available in countryspecific, regional, and multilateral financial safety nets tripling between 2007 and 2016 including through the creation of regional financing arrangements, expanded IMF resources and international reserve holdings (IMF 2018b). ${ }^{15}$ There are also now an estimated 160 bilateral swap lines between central banks around the world (Bahaj and Reis 2018).

\subsection{Striking the right balance}

EMDEs need to navigate a difficult terrain as debt has grown to record highs. They face weaker growth prospects driven by multiple structural factors. Yet, they also have pressing investment needs to achieve development goals and improve people's living standards. A key current challenge for EMDEs is to find the right balance between taking advantage of the present low interest rate environment and avoiding the risks posed by excessive debt accumulation.

\footnotetext{
15 The global financial safety net has four layers: 1) self-insurance against external shocks using foreign reserves or fiscal space at the national level, 2) bilateral swap lines between countries, 3) regional financing arrangements, and 4) the global financial backstop provided by the IMF (IRC Taskforce on IMF Issues 2018).
} 
On the upside, the current financial environment appears to alleviate some risks associated with debt accumulation. In particular, global interest rates remain at very low levels, and they are expected to remain low for the foreseeable future. In addition, some EMDEs have better fiscal, monetary and financial sector policy frameworks now in previous debt waves. A number of major reforms have been undertaken to make the global financial safety net more secure.

However, the study of the past three global waves of debt suggests reasons for caution. Despite currently low real interest rates, stronger policy frameworks and a more secure global safety net, the current episode of widespread debt accumulation could follow the historical pattern and once again lead to financial crises.

In a highly uncertain global environment, EMDEs face a wide range of risks, including the possibility of disruptions in advanced-economy financial markets, steep declines in commodity prices, trade tensions, and a sudden deterioration in China's corporate debt market. Materialization of any of these risks could lead to a sharp rise in global interest rates, a spike in risk premia or a sharp deterioration in growth prospects and, in turn, trigger debt distress in EMDEs. In addition to their record debt buildup since the global financial crisis, EMDEs have accumulated other vulnerabilities that could increase the risks and costs of debt distress.

As a result, low or falling global interest rates provide no sure protection against financial crises. Indeed, historically, half of all crises during episodes of rapid debt accumulation occurred in years when U.S. long-term (10-year) interest rates were falling and one-eighth of episodes occurred in years when U.S. long-term real interest rates were below 1 percent (as they have been since 2016).

The study of the past three waves of debt indicates the critical role of policy choices in reducing the likelihood of the post-crisis debt buildup ending in crises and, if crises were to take place, in mitigating their impact. For EMDEs with sound fiscal positions and policy frameworks that provide strong assurance of long-term sustainability, low interest rates may offer an opportunity to undertake debt-financed productive spending to boost growth prospects if the cyclical position is appropriate. However, for economies with constrained fiscal positions or highly leveraged corporate sectors, the lessons from previous waves of debt call for caution.

\section{Major lessons}

The experience of historical periods of debt accumulation that resulted in crises offer many lessons for EMDEs today. These crises include the Latin American crisis in the 1980s, crises in LICs in the 1980s-90s, the East Asian financial crisis (and the Russia, Turkey and Argentine sovereign debt crises) during 1997-2001; and most recently the global financial crisis in 2008-09 (Kose et al. 2020; Nagle 2020).

Use debt efficiently. The present combination of weak global growth and low interest rates makes government debt accumulation an appealing option for EMDEs to boost growthfriendly spending (World Bank 2019a). However, it is critical that the debt be used for productive purposes to boost potential growth. Crises have historically been common in countries that wasted debt or used it to finance projects that were not growth enhancing. 
These include state-led industrialization in Latin America in the 1960s-70s, and real estate bubbles in other countries such as Thailand prior to the Asian Financial crisis.

Maintain a resilient debt composition. A debt composition tilted toward foreign currencydenominated, short-term, or nonresident-held debt makes countries more vulnerable to shifts in market sentiment, currency depreciation, or spikes in global interest rates and risk premia. Financial crises have been more likely when the share of short-term external debt was higher (Rodrik and Velasco 2000). During the Latin American crisis and the Asian financial crisis a high share of foreign currency-denominated debt meant that currency depreciations led to an increase in both debt servicing costs and debt ratios.

Regulation and supervision of the financial sector matter. Inadequate regulatory and supervisory regimes can encourage excessively risky lending and debt buildup. This was the case in the Asian financial crisis and in several economies in Europe and Central Asia prior to the global financial crisis. Conversely, a robust regulatory system can temper the incentive to take excessive risks resulting from the public safety net for the financial system (moral hazard).

Beware of external shocks (especially when there are domestic vulnerabilities). Crises have historically typically occurred when external shocks hit countries that had substantial domestic vulnerabilities, including reliance on external and short-term debt in conjunction with a fixed exchange rate and low levels of reserves (Bordo, Meissner, and Stuckler 2010; Claessens et al. 2014; Mishkin 1999). Countries with higher international reserve levels have been significantly more resilient to these types of shocks (Gourinchas and Obstfeld 2012). In addition to external shocks, domestic political shocks contributed to crises by increasing policy uncertainty and weakening investor sentiment.

Private debt can rapidly turn into government debt. Large private sector losses, including losses threatening bank solvency, and the materialization of contingent liabilities, including those of state-owned enterprises, can lead governments to provide substantial financial support (Mbaye, Moreno-Badia, and Chae 2018). This was a particular issue in East Asian countries during the Asian financial crisis, with governments providing substantial support to banks. While the provision of government support can save a banking system from collapse, it can also lead to a steep jump in public debt (Bova et al. 2016; Claessens et al. 2014; World Bank 2015). Fiscal space can shrink rapidly as a result even though fiscal deficits may have been moderate.

Develop effective mechanisms to recognize losses and restructure debt. Having mechanisms in place to promptly recognize and restructure debt can improve the prospects for recovery from crisis, particularly public debt crises (Haldane et al. 2005; Kroszner 2003) or banking crises (Rutledge et al. 2012). The protracted resolution after the Latin American crises of the 1970s and 1980s and the debt crises in LICs in the 1980s and 1990s were associated with a period of very low, or even negative, per capita income growth. Growth only rebounded after the Brady plan and debt initiatives, such as Heavily Indebted Poor Countries Initiative and Multilateral Debt Relief Initiative, resolved debt distress and reduced debt overhangs. 


\section{Policy implications}

As documented above, policy frameworks in many EMDEs have improved over the past 20 years. These improvements played a critical role in mitigating the adverse impact of the global financial crisis on EMDEs in 2009 onwards. However, there is still considerable scope for further improvement. Specific policy priorities ultimately depend on country circumstances but there are four broad strands of policies that can help contain the risks associated with the recent debt accumulation.

\subsection{Policies for managing debt}

Governments need to put in place mechanisms and institutions that help them strike the proper balance between the benefits and costs of additional debt. These include sound debt management, high debt transparency, and thorough monitoring of contingent liabilities. While these policies mostly apply to borrowers, creditors also need to implement measures to mitigate risks associated with excessive debt accumulation.

Sound debt management can help reduce borrowing costs, enhance debt sustainability, and limit fiscal risks. ${ }^{16}$ Debt managers are increasingly adopting proactive policies to build buffers and make the composition of debt more resilient, but further progress is needed (World Bank 2013). Prudent debt management favors debt contracted on terms that preserve macroeconomic and financial resilience - preferably at longer maturities, at fixed (and favorable) interest rates, and in local currency. A debt composition that is less vulnerable to market disruptions reduces the likelihood that a decline in market sentiment, sharp depreciations, or interest rate spikes will erode debt sustainability. A well-developed and liquid domestic bond market can reduce the need for foreign-currency denominated lending and help ensure stability in government financing (Árvai and Heenan 2008; World Bank and IMF 2001).

Transparent balance sheets are a prerequisite for sound debt management. Public debt spikes can result from the revelation of previously undisclosed liabilities (Jaramillo, MulasGranados, and Jalles 2017; Weber 2012). Greater fiscal transparency is associated with lower borrowing costs, improvements in government effectiveness and lower government debt (Kemoe and Zhan 2018; Montes, Bastos, and de Oliveira 2019). Improvements in data collection practices for LIC debt can help policymakers undertake better-informed borrowing decisions, and have been associated with lower borrowing costs (Cady and Pellechio 2006; World Bank and IMF 2018). Principles and guidelines for debt transparency have been created, both by international institutions, such as the IMF's fiscal transparency code, and by the private sector (IIF 2019; IMF 2019c).

Monitoring and mitigation of contingent government liabilities are integral for sound public debt management. Recent survey evidence suggests that most public debt managers monitor risks of contingent liabilities but that only a minority uses risk mitigation tools, such as reserve accounts (40 percent of respondents) or risk exposure limits on contingent liabilities (30 percent of respondents; Lee and Bachmair 2019).

\footnotetext{
${ }^{16}$ Recognizing the need for better debt management, the World Bank and IMF have developed guidelines, best practices, and frameworks to assist countries in implementing debt management strategies (see World Bank and IMF (2001, 2009a, 2009b, 2014), and Abbas, Pienkowski, and Rogoff (2019)).
} 
Creditors, including international financial institutions, play an important role in mitigating the risks associated with debt accumulation. They need to ensure that their own lending practices are prudent. More broadly, while country authorities have the primary responsibility to transparently report their debt data, international financial institutions work to support such transparency and sustainable lending practices in several ways. The IMF and the World Bank collect and disseminate debt statistics that are used by a wide range of stakeholders; produce reports of public debt data at the country level via joint debt sustainability analyses; support countries' efforts to produce medium-term debt management strategies; publish information on countries' borrowing capacity; and directly liaise with other multilateral, bilateral, and private creditors (World Bank and IMF 2009a, 2009b).

\subsection{Macroeconomic policies}

Notwithstanding substantial improvements since the 1990s, macroeconomic policy frameworks can be strengthened further in many EMDEs (World Bank 2019b). Monetary policy frameworks and exchange rate regimes can be strengthened to increase central bank credibility. Fiscal frameworks can ensure that borrowing remains within sustainable limits and borrowed funds are used well.

The benefits of stability-oriented and resilient monetary policy frameworks cannot be overstated. During episodes of financial stress, when EMDE currencies tend to depreciate sharply, strong monetary policy frameworks will be helpful not least because the exchange rate pass-through to inflation tends to be smaller in countries with more credible, transparent, and independent central banks; inflation-targeting monetary policy regimes; and better-anchored inflation expectations (Kose et al. 2019). Flexible exchange rates can provide an effective mechanism for macroeconomic adjustment and help avoid currency overvaluations, as well as preventing the buildup of large currency mismatches on balance sheets - a common precursor of crises.

Fiscal rules can help prevent fiscal slippages, ensure that revenue windfalls during times of strong growth are prudently managed, and contain and manage risks from contingent liabilities. ${ }^{17}$ Strong fiscal frameworks have also been associated with lower inflation and inflation volatility, supporting the central bank in delivering its mandate (Ha, Kose, and Ohnsorge 2019). EMDEs have made important strides in the adoption and design of fiscal rules (Schaechter et al. 2012). ${ }^{18}$ However, fiscal rules may be effective only once a certain degree of broader government effectiveness is achieved and sound budgetary institutions are in place. ${ }^{19}$

\footnotetext{
${ }^{17}$ For detailed discussions of fiscal rules, see Cebotari (2008), Currie and Velandia (2002), Romer and Romer (2019), and Ülgentürk (2017).

${ }_{18}$ Schaechter et al. (2012) create a fiscal rule index that captures both the number and characteristics of fiscal rules in operation in advanced economies and EMDEs and show how EMDEs have played catch-up to advanced economies since 2000. Ardanaz et al. (2019) find that well-designed fiscal rules can help safeguard public investment during downturns.

${ }^{19}$ Calderón, Duncan, and Schmidt-Hebbel (2016) estimate that fiscal and monetary policy procyclicality is greater in countries with weak institutions. Bergman and Hutchison (2015, 2018) show that fiscal rules are effective only when government effectiveness exceeds a minimum threshold. World Bank (2015) discusses the circumstances and features that can make fiscal rules more effective.
} 
Alternatives to debt accumulation are available to expand fiscal resources for priority spending. Public spending can be reallocated to uses that are more likely to boost future growth, including education and health spending as well as to climate-smart infrastructure investment to strengthen economic resilience. Government revenue bases can be broadened by removing special exemptions and strengthening tax administration. ${ }^{20}$ Governments can also take action to foster private sector-led growth. Reform agendas to improve business climates and institutions have resulted in significant gains in investment and productivity in EMDEs (World Bank 2018a). In turn, increased private sector growth could expand the revenue base and, ultimately, strengthen government revenues.

\subsection{Financial sector policies}

Robust financial sector regulation and supervision can help prevent risks from building up. Financial market deepening can help mobilize domestic savings that may provide more stable sources of financing than capital inflows.

Improved financial system regulation and supervision, by acting on systemic exposures and ensuring adequate capital buffers, can help prevent risks from building up. Robust prudential regulation and supervision can help pre-empt the buildup of systemic financial weaknesses. Macroprudential policies can help moderate lending to households and corporates. The use of living wills for banks and robust bank bankruptcy regimes can help with the orderly winding down of insolvent institutions, including through the bail-in of creditors. Credibility and predictability of bank resolution can help prevent spillovers from the failure of one financial institution to others by reassuring creditors about the continued functioning of the financial system as a whole (Hoshi 2011).

Financial market deepening can help expand the pool of stable long-term domestic savings available for domestic investment. This requires an enabling environment of robust institutions, protection of creditor rights, sound regulatory quality, and macroeconomic stability (Laeven 2014; Sahay et al. 2015). At the same time, however, excessively rapid growth in financial markets can increase financial stability risks. A careful balance between measures to promote financial market deepening and supervision and regulation is therefore critical.

\subsection{Strengthening institutions}

Well-enforced frameworks for sound corporate governance can help ensure that funds borrowed by private corporates are well used. Sound bankruptcy frameworks can help prevent debt overhangs from weighing on investment for prolonged periods.

The promotion of good corporate governance can mitigate risks arising from the corporate sector. Stronger corporate governance can tilt firms' financing towards equity rather than debt (Mande, Park, and Son 2012); increase hedging of foreign currency positions to protect against external shocks (Lel 2012); and encourage more efficient firm operation (Henry 2010). Other measures can also help contain risks from corporate credit growth, such as increased stress testing of listed corporates' balance sheets.

\footnotetext{
${ }^{20}$ For a discussion of these policies, see Gaspar, Ralyea, and Ture (2019), IMF (2019a), and World Bank (2017b).
} 
Effective bankruptcy and insolvency regimes can both help in the resolution of private debt crises and have benefits outside of crises (Leroy and Grandolini 2016). Several EMDEs have recently reformed bankruptcy procedures, but in general, EMDE bankruptcy protection laws lag international best practices. ${ }^{21}$ Strengthening bankruptcy protection can boost investment and facilitate responsible corporate risk-taking, helping to relieve the costs of debt overhang. Well-functioning legal, regulatory, and institutional frameworks are crucial for commercial banks and companies to resolve non-performing loans, and facilitate business exit and reorganization (Menezes 2014). A robust insolvency regime can improve financial inclusion and increase access to credit, by reducing the cost of lending.

\section{Conclusion}

This paper considered how the most recent buildup of debt in EMDEs might evolve, and whether it could seven lessons from past episodes of debt accumulation and debt-related crises. It found two main messages.

The post-crisis global debt buildup has been unprecedented in its size, speed, and reach in emerging market and developing economies. Similar debt buildups in the past halfcentury led to widespread financial crises in these economies. As debt vulnerabilities mount amid weak growth, continued low global interest rates provide no sure protection against financial crises. The historical record suggests that borrowing costs could increase sharply - or growth could slow steeply - for a wide range of reasons, including heightened risk aversion and rising country risk premia. A sudden increase in borrowing costs and associated financial pressures would take place against the challenging backdrop of weak growth prospects, mounting vulnerabilities, and elevated global risks.

History shows that policies matter. Robust macroeconomic, financial, and structural policies can help countries strike the right balance between the costs and the benefits of debt accumulation. Such policies are also critical to help reduce the likelihood of financial crises and alleviate their impact, if they erupt. Although some emerging and developing economies have better policy frameworks now than during previous debt waves, there remains significant room for improvement.

The paper shows that there has already been a significant stock of knowledge about the implications of debt accumulation, but it also points to several avenues for future research into how the latest buildup may evolve, and to evaluate policy responses in more detail.

First, whereas much of the literature on the cost of debt has examined the experience of EMDEs, most of the literature on the benefits of debt has examined only advanced economies. Less is therefore known about the benefits of debt in environments with limited financial market development, short-lived governments, poor public expenditure management, and fragile investor confidence.

Second, the exceptionally fast and broad-based debt buildup in EMDEs since the global financial crisis has coincided with a period of slowing investment and productivity growth. This raises concerns about the productive use of the funds raised through debt

\footnotetext{
${ }^{21}$ This includes a new bankruptcy law in Egypt, a strengthening of secured creditors' rights in India, and the establishment of new restructuring mechanisms in Poland.
} 
accumulation. At the firm or sectoral level, future research could further explore the link between debt accumulation and productivity growth; at the aggregate level, it could examine more closely the link between debt accumulation and public investment.

Third, given growing concern about debt transparency, further investigation of its importance in previous crises would be a timely contribution. This would include an indepth assessment of debt crises triggered by problems related to debt transparency, such as the revelation of hidden debt or the realization of contingent liabilities, including from state owned enterprises, public-private partnerships, subnational borrowing, collateralized lending or other explicit and implicit lending guarantees.

Fourth, a large literature explores the role of various vulnerabilities, including debt composition, in financial crises. However, there is limited analysis of the role of institutional weakness. Future research could examine in greater depth how specific institutional frameworks, such as fiscal rules, inflation targeting, or robust financial supervision and regulation, can reduce the frequency and impact of crises. 


\section{Figure 1. Evolution of debt}

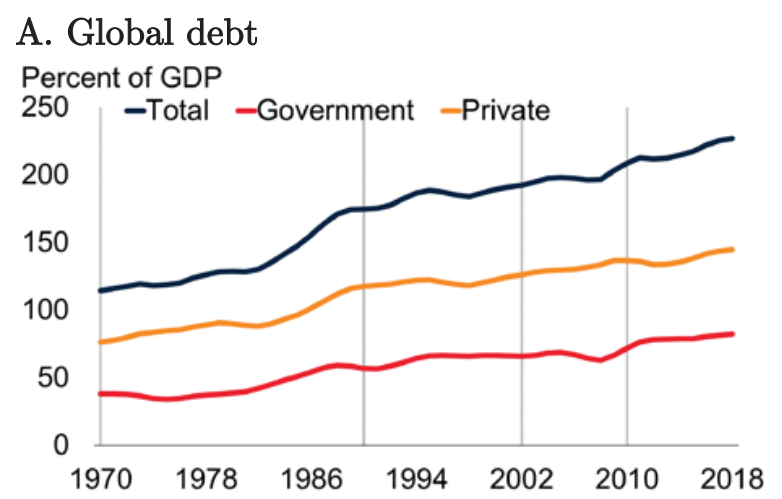

B. Debt in EMDEs

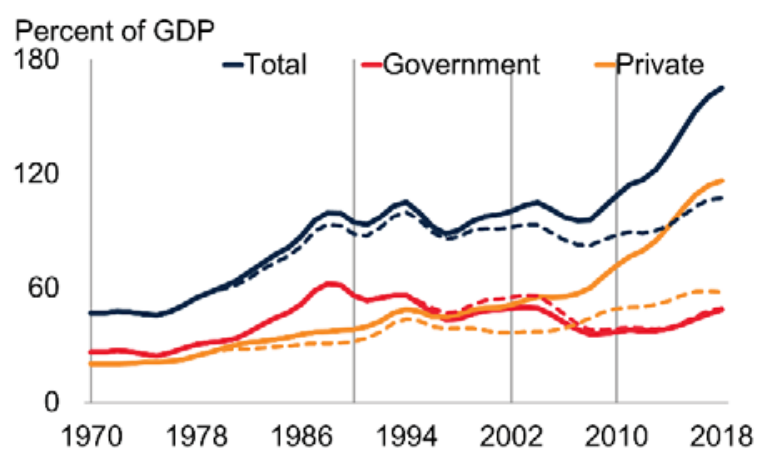

Source: International Monetary Fund; World Bank.

Note: Aggregates calculated using current U.S. dollar GDP weight and shown as a 3-year moving average. Dashed lines refer to EMDEs excluding China. Vertical grey lines indicate beginning and end of four waves of global debt accumulation. The first wave runs from 1970-89, the second wave from 1990-2001; the third wave from 2002-09; and the fourth wave from 2010 onwards. 
Figure 2. Post-crisis debt accumulation and growth

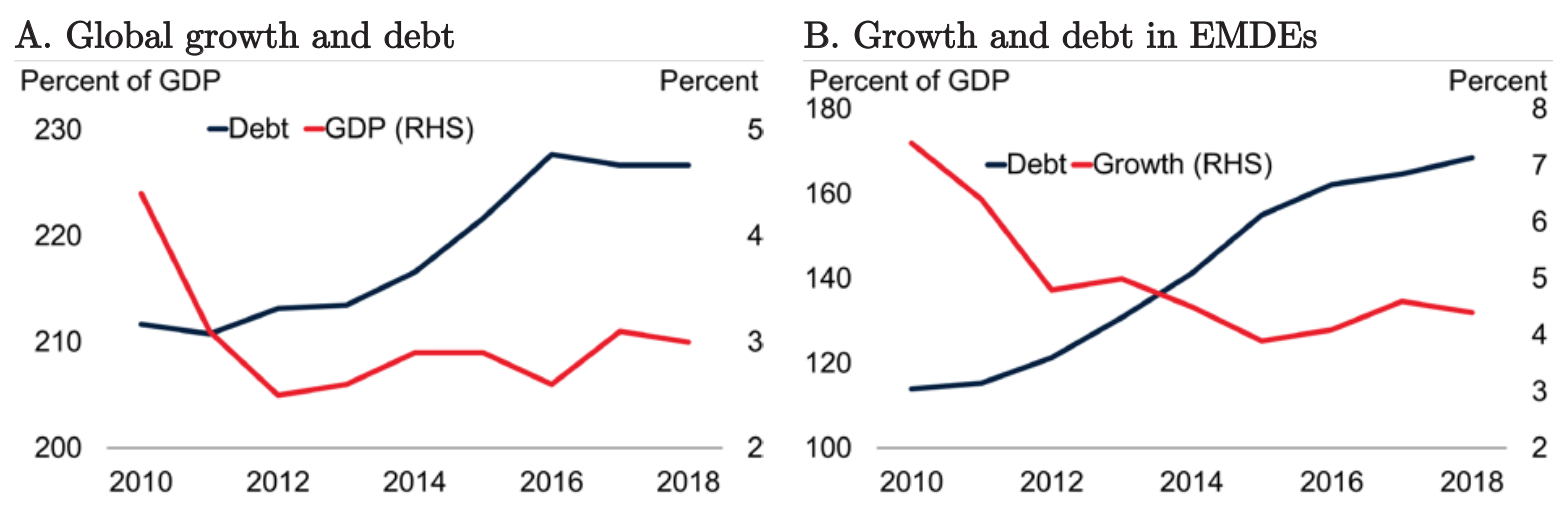

Source: World Bank.

Note: Total debt (in percent of GDP) and real GDP growth (GDP-weighted at 2010 prices and exchange rates). 
Figure 3. Global waves of debt

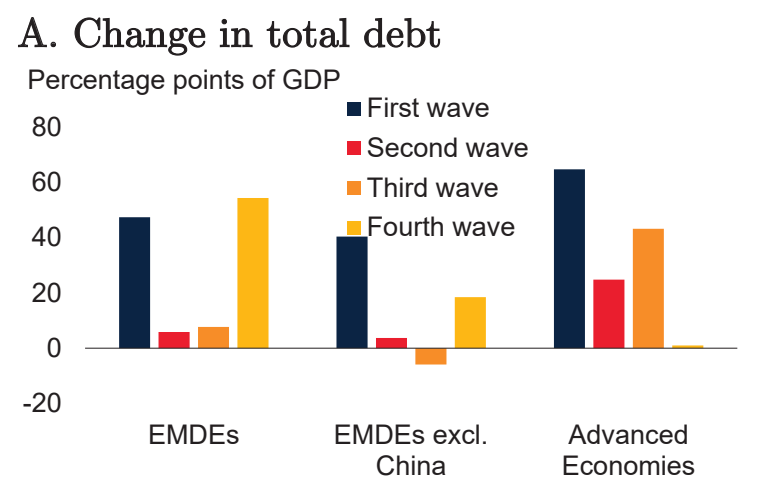

\section{B. Average annual change in total debt}

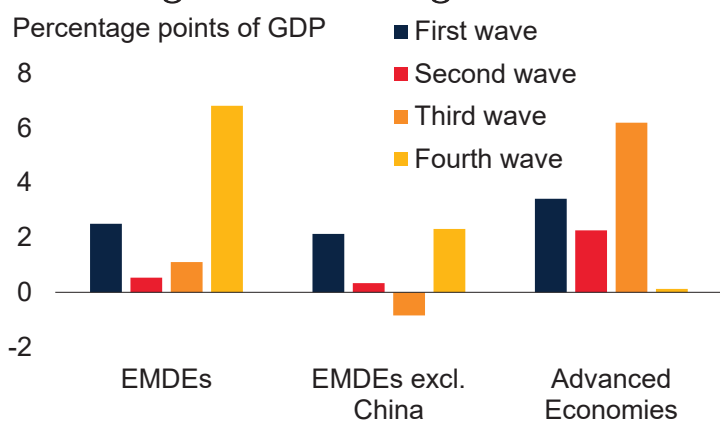

C. U.S. policy interest rates

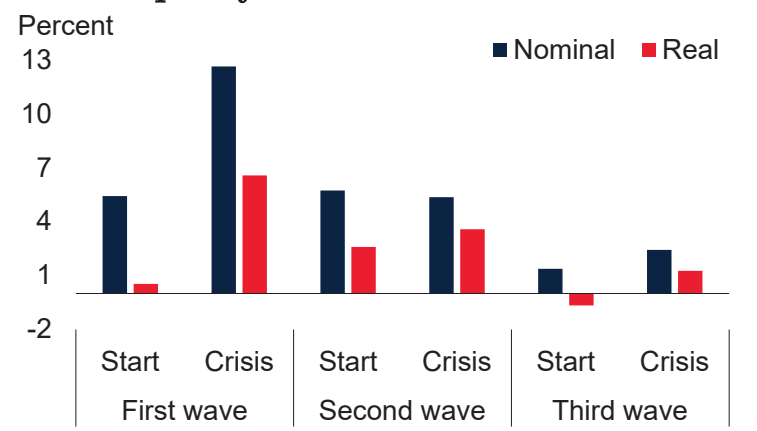

D. Capital flows to EMDEs

Percent of GDP

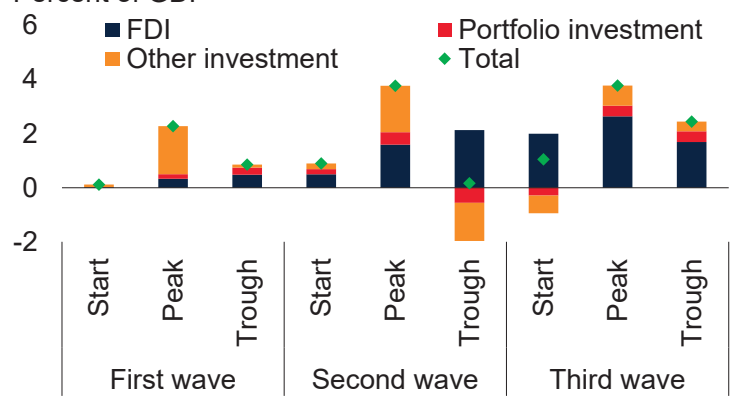

Source: Haver Analytics; International Monetary Fund; World Bank.

A. B. Cumulative (A) or average annual (B) change in total debt from the start to the end of each global wave of debt. The first wave runs from 1970-89, the second wave from 1990-2001; the third wave from 2002-09; and the fourth wave from 2010. Average annual change calculated as total increase in debt-to-GDP ratios over the duration of a wave, divided by the number of years in a wave.

C. Start of a wave defined as the first three years of the wave. Crisis defined as the year before, and year of, widespread crises. First wave: 1970-72 and 1981-82; second wave: 1990-92 and 1996-97; third wave: 2002-04, and 2008-09. Real interest rates are deflated by the GDP deflator.

D. Net capital inflows to EMDEs. The start of each wave is the first year, the peak is the year of peak capital inflows before the start of crises, and the trough is the year of lowest capital inflows after the crisis. First wave: 1970, 1978, and 1988; second wave: 1990, 1995, and 2000; third wave: 2002, 2007, and 2009. 
Figure 4. Interest rates and inflation

\section{A. Long-term interest rates}

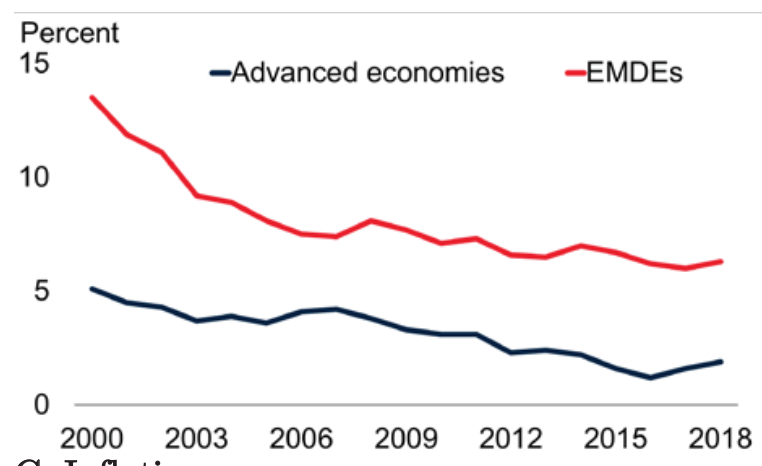

\section{Inflation}

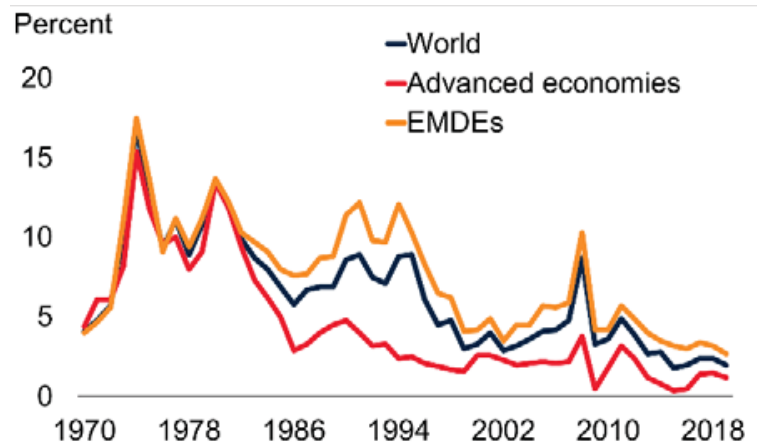

B. Policy rate expectations in major advanced economies

\section{Percent}

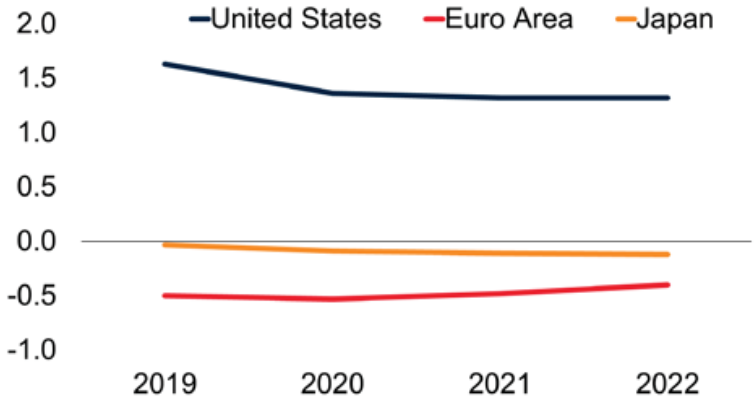

\section{Inflation expectations}

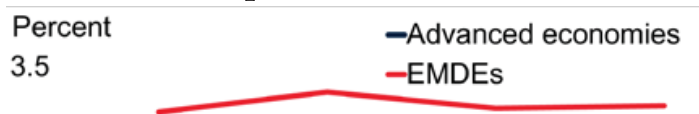

3.0

2.5

2.0

1.5

1.0

$20192020 \quad 2021 \quad 2022$

Source: Bloomberg; Consensus Economics; International Institute of Finance; Kose et al. (2017); Ha, Kose, and Ohnsorge (2019); World Bank.

A. Average long-term nominal government bond yields (with maturity of 10 years or close) computed with current U.S. dollar GDP as weights, for up to 36 advanced economies and 84 EMDEs.

B. Market implied policy rates. Expected rates based on overnight index swap (OIS) forward rates.

C. Median annual average inflation.

D. Median inflation expectations, based on consensus forecasts in October 2019. 
Figure 5. Debt trajectories

A. Instances of interest rates below growth, 1990-2018

B. Countries with real interest rates below growth

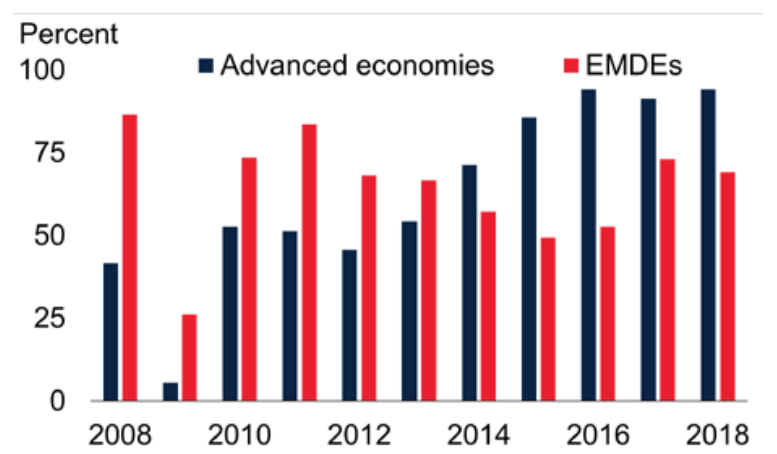

\section{Percent of country-year pairs}

80

- Stable or falling trajectory

- Rising trajectory

60

40

20

0

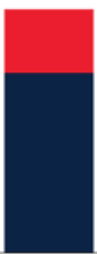

World Advanced economies EMDEs

Source: Kose et al. (2017); World Bank.

A. Share of country-year pairs in each group when long-term nominal interest rates (represented by 10-year local currency government bond yields or with close maturity) are below nominal GDP growth for 1990-2018 in up to 34 advanced economies and 83 EMDEs. Red bars indicate the share of country-year pairs in which debt is on a rising trajectory, notwithstanding interest rates below growth rates; blue bars indicate country-year pairs in which debt is on a stable or declining trajectory.

B. Share of countries where long-term nominal interest rates (represented by 10-year local currency government bond yields or with close maturity) are below nominal GDP growth. Sample of up to 36 advanced economies and 84 EMDEs. 
Figure 6. Sovereign and corporate vulnerabilities in EMDEs

A. Government debt

\section{Number of economies}

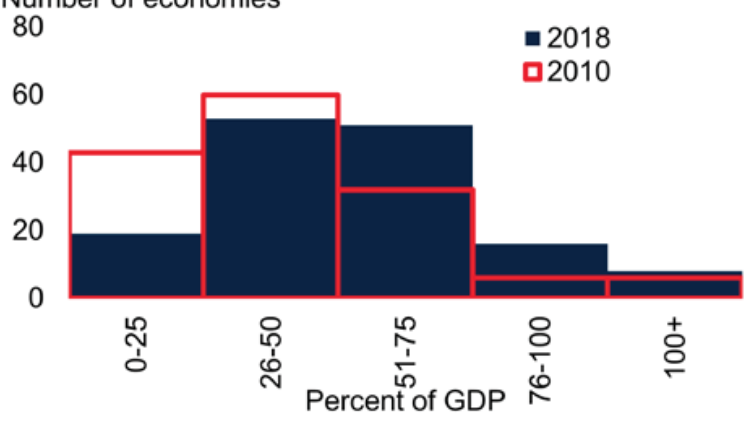

C. Maturity of government debt

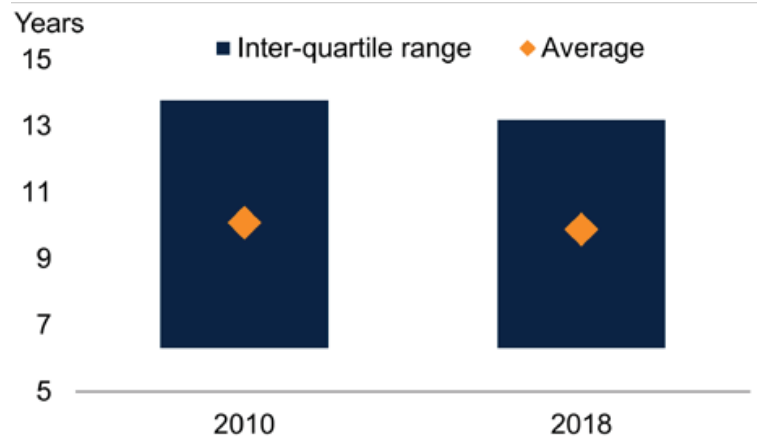

E. Non-financial corporate debt

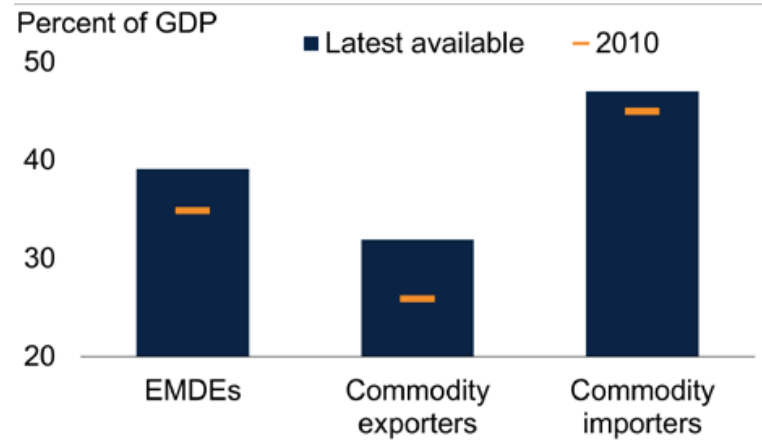

B. Sovereign credit ratings

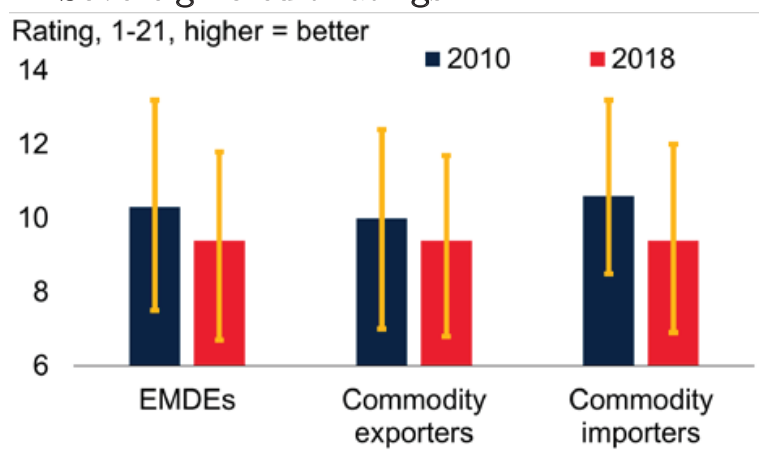

D. Cyclically-adjusted primary fiscal balance Number of economies
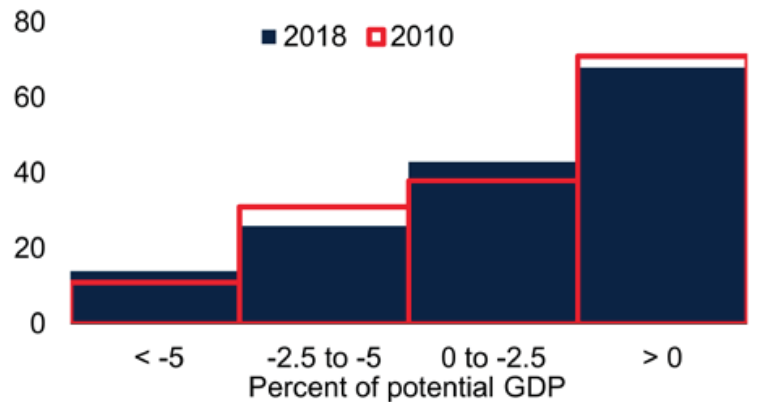

F. Non-financial corporate debt

Number of economies

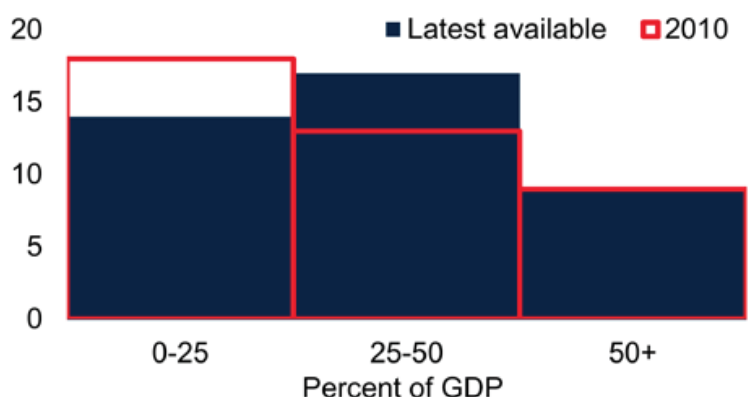

Source: International Monetary Fund, Kose et al. (2017), World Bank.

A. Based on data for 147 EMDEs.

B Unweighted averages of foreign currency sovereign credit ratings for 49 EMDE commodity exporters and 40 EMDE

commodity importers. Whiskers denote interquartile ranges.

C. Unweighted averages of the average maturity of government debt based on 39 EMDEs.

D. Based on data for 151 EMDEs.

E.F. Based on data for 40 EMDEs. Latest available datapoint is 2019Q2 for Argentina, Brazil, Chile, China,

Colombia, Hungary, India, Indonesia, Malaysia, Mexico, Poland, Russia, Saudi Arabia, South Africa, Thailand, and Turkey and 2017 for other economies.

E. Unweighted average of nonfinancial corporate debt in 21 EMDE commodity exporters and 19 EMDE commodity importers. 
Figure 7. External vulnerabilities in EMDEs

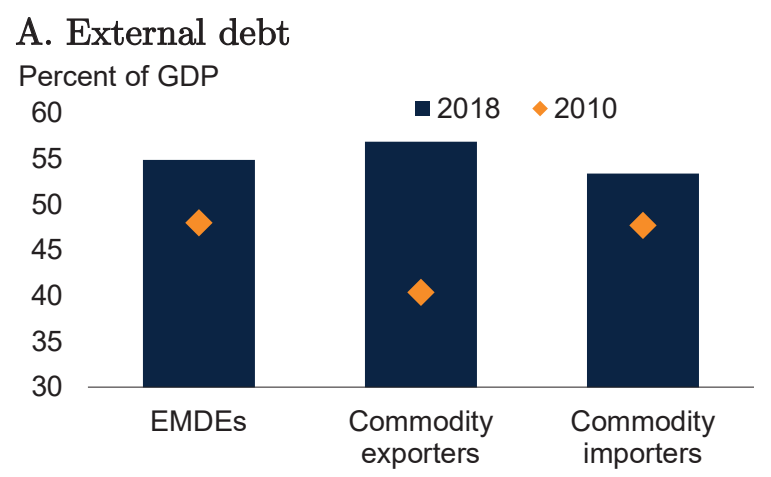

C. Current account balance

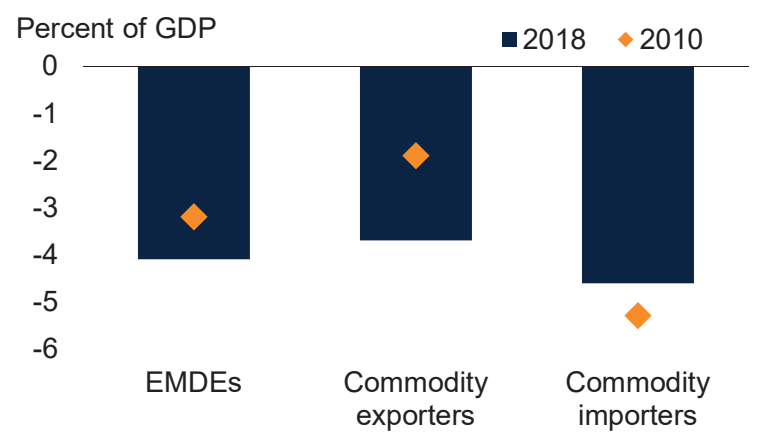

\section{E. Foreign reserves adequacy}

\section{ARA metric}

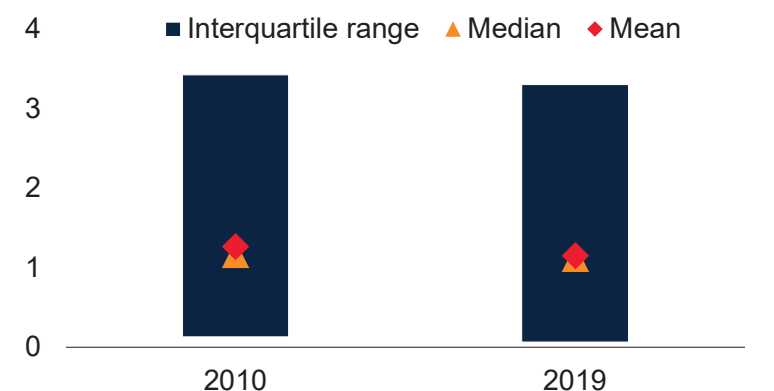

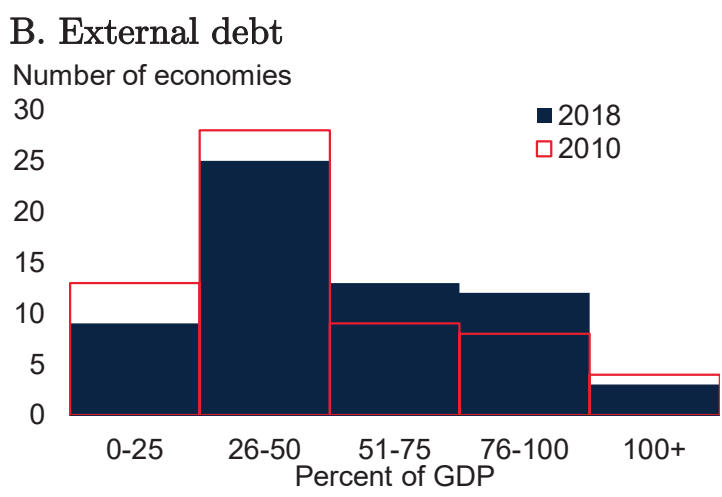

D. Current account balance

Number of economies

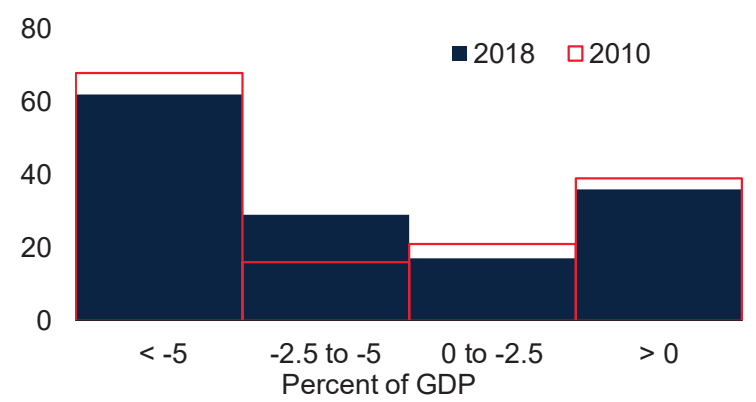

F. Non-resident holdings of local-currency debt Percent of total debt

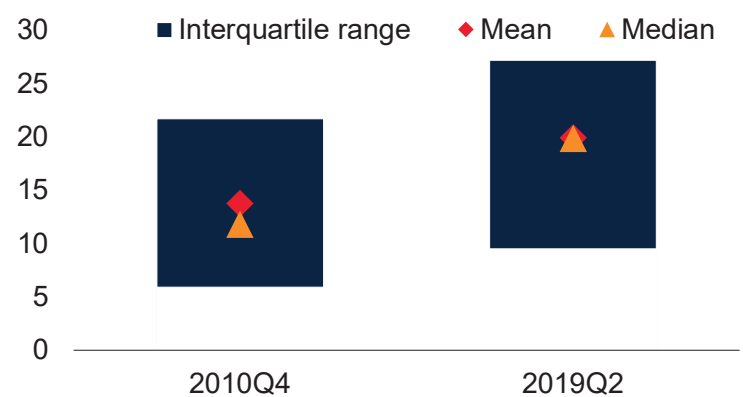

Source: Ha, Kose, and Ohnsorge (2019); International Monetary Fund; World Bank.

A. Unweighted average of total external debt-to-GDP ratios for 31 EMDE commodity exporters and 30 EMDE commodity importers.

B. Based on data for 61 EMDEs.

C. Unweighted average of current account balance-to-GDP ratios for 88 EMDE commodity exporters and 56 EMDE commodity importers.

D. Based on data for 144 EMDEs.

E. Based on data for 48 EMDEs. Dark blue bars show minimum and maximum values. Assessing reserve adequacy (ARA) metric is based on IMF (2011) which determines the appropriate reserve cover on a risk-weighted basis covering short-term debt, medium and long-term debt, and equity liabilities. Broad model and export earnings. Risk weights are based on observed outflows during periods of exchange rate pressure. Values above 1 suggest that countries are fully able to meet balance of payments needs using reserves.

F. Based on data for 22 EMDEs. 


\section{Figure 8. Fiscal outcomes in EMDEs around oil price plunges}

\section{A. Fiscal sustainability gap}

\section{Percent of GDP}

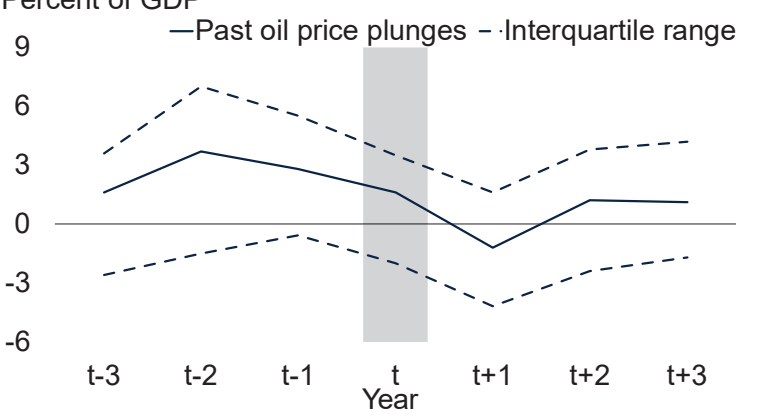

\section{Overall fiscal balance}

Percent of GDP

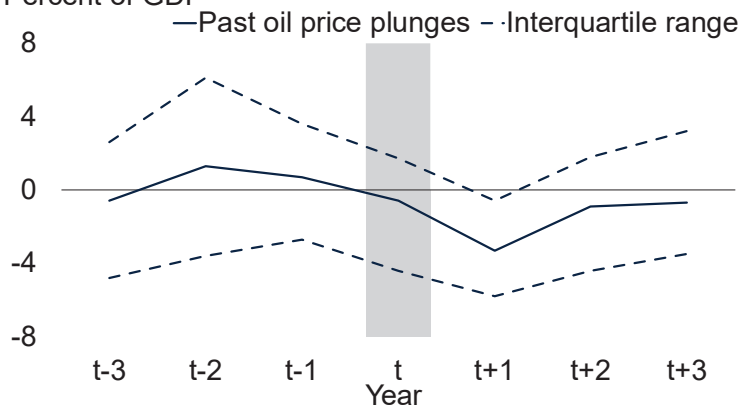

B. Government debt

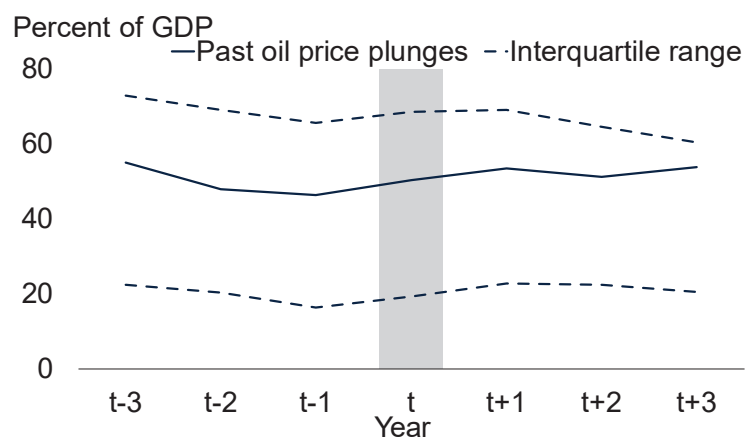

D. Credit to the private sector Percent of GDP

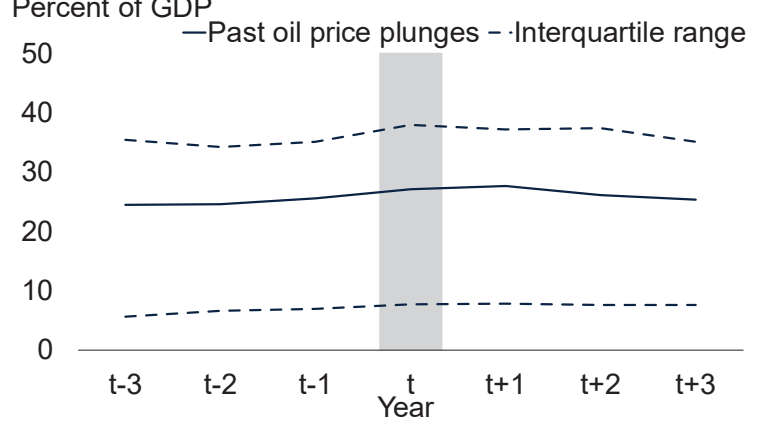

Source: International Monetary Fund, World Bank (2017a).

Note: Year t refers to the year of oil price plunges. Past oil price plunges include collapses in global oil prices in 1991, 1998, 2001, and 2008 (World Bank 2015). Simple averages of 36 EMDE oil exporters in all episodes.

C. Samples are restricted to episodes where data on sustainability gaps are available. 
Figure 9. Policy frameworks in EMDEs

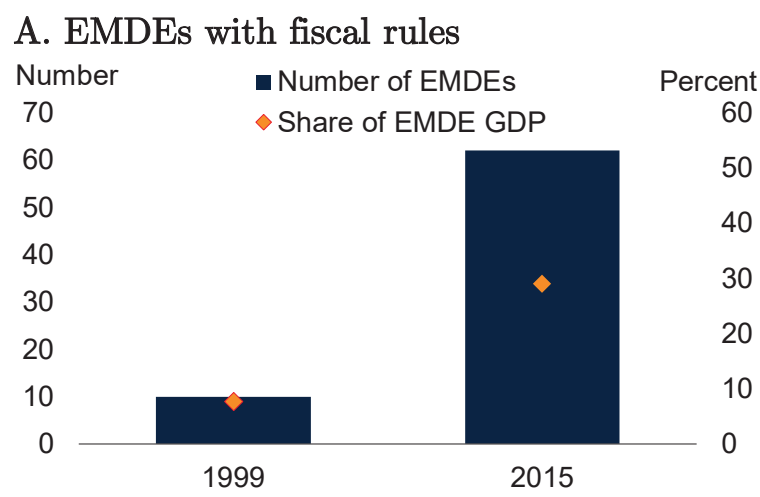

C. EMDEs with flexible exchange rates

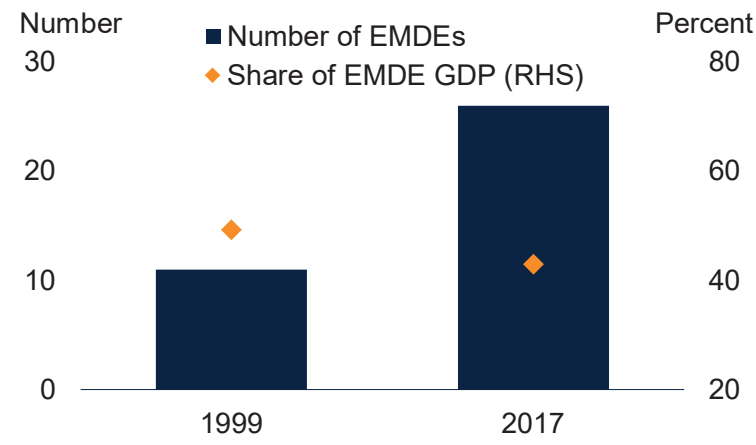

E. Macroprudential policy in EMDEs

Index, 12=Most tools

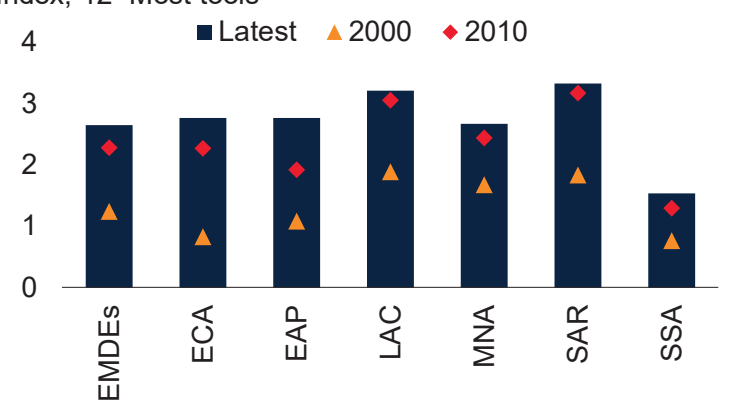

B. EMDEs with inflation targeting

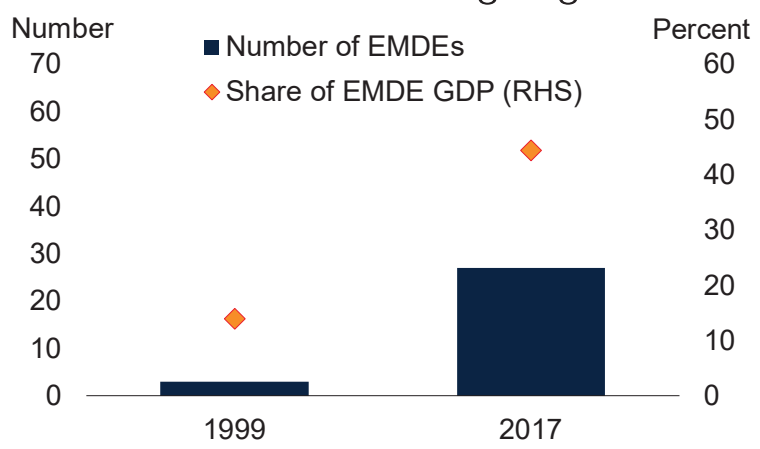

D. Central Bank transparency in EMDEs Index

$80 \quad 6$

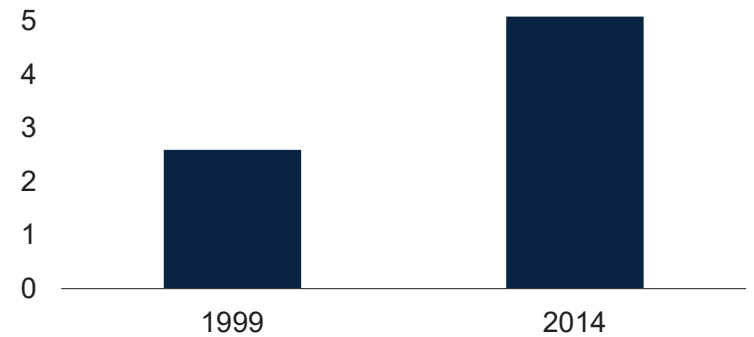

F. Bankruptcy rights protection in EMDEs Distance to frontier score, 100=best

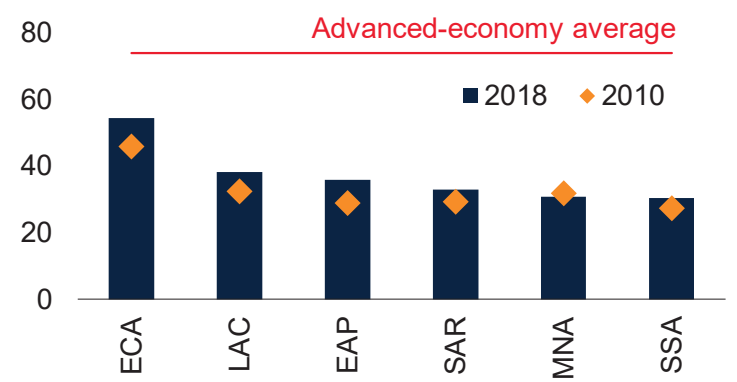

Source: Cerutti, Claessens and Laeven (2017); International Monetary Fund; Kose et al. (2017); Dincer and Eichengreen (2014); Ha, Kose, and Ohnsorge (2019); World Bank.

A. An economy is considered to be implementing a fiscal rule if it has one or more fiscal rules on expenditure, revenue, budget balance, or debt.

B. Inflation targeting as classified in the IMF's Annual Report of Exchange Arrangements and Exchange Restrictions (AREAER).

C. An economy is considered to have a flexible exchange rate if it is classified as "floating" or "free floating" in the IMF AREAER.

D. Dincer and Eichengreen Transparency Index. The index ranges from 0 (least independent and transparent) to 15 (most independent and transparent).

E. Sample includes 123 EMDEs. Unweighted average of the macroprudential policy index of Cerutti, Claessens and Laeven (2017). The macroprudential policy index measures the number of tools used by authorities and is based on a simple sum of up to 12 including, but not limited to, the countercyclical capital buffer and loan-to-value ratios. F. Distance to frontier score for strength of insolvency resolution. A higher index indicates reforms that improve the business climate. EAP, ECA, LAC, MNA, SAR, and SSA include 22, 22, 32, 19, 8, and 46 economies, respectively. Advanced economies include 36 economies. Based on World Bank Doing Business report. 


\section{References}

Abbas, A., A. Pienkowski, and K. Rogoff. 2019. Sovereign Debt: A Guide for Economists and Practitioners. New York: Oxford University Press.

Acevedo, S. 2016. "Gone with the Wind: Estimating Hurricane and Climate Change Costs in the Caribbean." IMF Working Paper 16/199, International Monetary Fund, Washington, DC.

Alcidi, C., and D. Gros. 2019. "Public Debt and the Risk Premium: A Dangerous Doom Loop." VoxEU.org, May 22.

Ahmed, S., R. Correa, D. A. Dias, N. Gornemann, J. Hoek, A. Jain, E. Liu, and A. Wong. 2019. "Global Spillovers of a China Hard Landing." International Finance Discussion Papers 1260, Federal Reserve Board of Governors, Washington, DC.

Alfaro, L., and F. Kanczuk. 2016. "Fiscal Rules and Sovereign Debt." NBER Working Paper 23370, National Bureau of Economic Research, Cambridge.

Andreasen, E., G. Sandleris, and A. Van der Ghote. 2019. "The Political Economy of Sovereign Defaults." Journal of Monetary Economics 104 (June): 23-36.

Ardanaz, M., E. Cavallo, A., Izquierdo, and J. Puig. 2019. "Growth-Friendly Fiscal Rules? Protecting Public Investment from Budget Cuts Through Fiscal Rule Design." IDB Discussion Paper 698, Inter-American Development Bank, Washington, DC.

Arteta, C., and S. Kasyanenko. 2019. "Financial Sector Developments." In A Decade After the Global Recession: Lessons and Challenges for Emerging and Developing Economies, edited by M. A. Kose and F. Ohnsorge. Washington, DC: World Bank.

Arteta, C., M. A. Kose, M. Stocker, and T. Taskin. 2016. "Negative Interest Rate Policies: Sources and Implications." Policy Research Working Paper 7791, World Bank, Washington, DC.

Árvai, Z., and G. Heenan. 2008. "A Framework for Developing Secondary Markets for Government Securities." IMF Working Paper 08/174, International Monetary Fund, Washington, DC.

Auerbach, A. J., W. G. Gale, and A. Krupkin. 2019. "If Not Now, When? New Estimates of the Federal Budget Outlook." Brookings Report, February 11, Brookings Institution, Washington, DC.

Bahaj, S., and R. Reis. 2018. "Central Bank Swap Lines." CESifo Working Paper 7124, CESifo, Munich.

Barattieri, A., M. Cacciatore, and F. Ghironi. 2018. "Protectionism and the Business Cycle." NBER Working Paper 24353, National Bureau of Economic Research, Cambridge.

BCBS (Basel Committee on Banking Supervision). 2019. Sixteenth Progress Report on Adoption of the Basel Regulatory Framework. Basel: Basel Committee on Banking Supervision.

Bergman, U. M., and M. Hutchison. 2015. "Economic Stabilization in the Post-Crisis 
World: Are Fiscal Rules the Answer?" Journal of International Money and Finance 52 (April): 82-101.

2018. "Fiscal Procyclicality in Developing Economies: The Role of Fiscal Rules, Institutions and Economic Conditions." Unpublished paper, University of Copenhagen, Copenhagen.

BIS (Bank for International Settlements). 2018. "Structural Changes in Banking After the Crisis." CGFS Papers 60, Committee on the Global Financial System, Bank for International Settlements, Basel.

Settlements.

2019. Credit to the Nonfinancial Sector Statistics. Basel: Bank for International

Blanchard, O. 2019. "Public Debt and Low Interest Rates." American Economic Review 109 (4): 1197-1229.

Blanchard, O., and L. H. Summers. 2019. Evolution or Revolution? Rethinking Macroeconomic Policy After the Great Recession. Cambridge: MIT Press.

Bordo, M, M. Dueker, and D. Wheelock. 2003. "Aggregate Price Shocks and Financial Stability: The United Kingdom 1796-1999." Explorations in Economic History 40 (2): 143169.

Bordo, M., C. Meissner, and D. Stuckler. 2010. "Foreign Currency Debt, Financial Crises and Economic Growth: A Long-run View." Journal of International Money and Finance 29 (4): 642-665.

Bova, E., M. Ruiz-Arranz, F. Toscani, and H. E. Ture. 2016. "The Fiscal Costs of Contingent Liabilities; A New Dataset." IMF Working Paper 16/14, International Monetary Fund, Washington, DC.

Boz, E., G. Gopinath, and M. Plagborg-Moller. 2017. "Global Trade and the Dollar." NBER Working Paper 23988, National Bureau of Economic Research, Cambridge.

Bruno, V., S. Kim, and H. Shin. 2018. "Exchange Rates and the Working Capital Channel of Trade Fluctuations." BIS Working Paper 694, Bank for International Settlements, Basel.

Bruno, V., I. Shim, and H. S. Shin. 2017. "Comparative Assessment of Macroprudential Policies." Journal of Financial Stability 28 (February): 183-202.

Bruno, V., and H. S. Shin. 2015. "Capital Flows and the Risk-Taking Channel of Monetary Policy." Journal of Monetary Economics 71 (April): 119-132.

Caballero, R. 2003. "The Future of the IMF." American Economic Review 93 (2): 31-38.

Cady, J., and A. Pellechio. 2006. "Sovereign Borrowing Cost and the IMF's Data Standards Initiatives." IMF Working Paper 06/78, International Monetary Fund, Washington, DC.

Calderón, C., R. Duncan, and K. Schmidt-Hebbel. 2016. "Do Good Institutions Promote Countercyclical Macroeconomic Policies?" Oxford Bulletin of Economics and Statistics 78 (5): 650-670. 
Carney, M. 2015. "Breaking the Tragedy on the Horizon-Climate Change and Financial Stability." Speech at Lloyd's of London, September 29, London.

Cebotari, A. 2008. "Contingent Liabilities: Issues and Practice." IMF Working Paper 245, International Monetary Fund, Washington, DC.

Cerutti, E., S. Claessens, and L. Laeven. 2017. "The Use and Effectiveness of Macroprudential Policies: New Evidence." Journal of Financial Stability 28 (February): 203-224.

Claessens, S. 2015. "An Overview of Macroprudential Policy Tools." Annual Review of Financial Economics 7 (December): 397-422.

Claessens, S., and M. A. Kose. 2014. "Financial Crises Explanations, Types, and Implications." In Financial Crises: Causes, Consequences, and Policy Responses, edited by S. Claessens, M. A. Kose, L. Laeven, and F. Valencia, 3-59. Washington, DC: International Monetary Fund.

Claessens, S., M. A. Kose, L. Laeven, and F. Valencia. 2014. Financial Crises: Causes, Consequences, and Policy Responses. Washington, DC: International Monetary Fund.

Correa, R., and H. Sapriza. 2014. "Sovereign Debt Crises." International Finance Discussion Paper 1104, May, Board of Governors of the Federal Reserve System, Washington, DC.

CRFB (Committee for a Responsible Federal Budget). 2019. "Why Should We Worry About the National Debt?" Mimeo, April 16, Committee for a Responsible Federal Budget, Washington, DC.

Cuadra, G., and H. Sapriza. 2008. "Sovereign Default, Interest Rates and Political Uncertainty in Emerging Markets." Journal of International Economics 76 (1): 78-88.

Currie, E., and A. Velandia. 2002. "Risk Management of Contingent Liabilities Within a Sovereign Asset-Liability Framework." Working Paper, World Bank, Washington, DC.

Del Negro, M., D. Giannone, M. P. Giannoni, and A. Tambalotti. 2017. "Safety, Liquidity, and the Natural Rate of Interest." Brookings Papers on Economic Activity 2017 (Spring): 235-316.

Dincer, N. N., and B. Eichengreen. 2014. "Central Bank Transparency and Independence: Updates and New Measures." International Journal of Central Banking 10 (1): 189-253.

Dizioli, A., and B. van Roye. 2018. "The Resurgence of Protectionism: Potential Implications for Global Financial Stability." In Financial Stability Review, November. Frankfurt: European Central Bank.

Eberhardt, M., and A. Presbitero. 2018. "Commodity Price Movements and Banking Crises." IMF Working Paper 18/153, International Monetary Fund, Washington, DC.

Eggertsson, G. B., N. R. Mehrotra, and J. A. Robbins. 2019. "A Model of Secular Stagnation: Theory and Quantitative Evaluation." American Economic Journal: Macroeconomics 11 (1): 1-48.

Eichengreen, B. 2019. "The Return of Fiscal Policy." Project Syndicate, May 13. 
Essl, S., S. Kilic Celik, P. Kirby, and A. Proite. 2019. "Debt in Low-Income Countries: Evolution, Implications, Remedies." Policy Research Working Paper 8794, World Bank, Washington, DC.

Fernald, J. 2016. "What is the New Normal for U.S. Growth?" FRBSF Economic Letter 2016-30, Federal Reserve Bank of San Francisco.

Feyen, E., S. Ghosh, K. Kibuuka, and S. Farazi. 2015. "Global Liquidity and External Bond Issuance in Emerging Markets and Developing Economies." Policy Research Working Paper 7373, World Bank, Washington, DC.

Frank, N., and H. Hesse. 2009. "Financial Spillovers to Emerging Markets During the Global Financial Crisis." IMF Working Paper 09/104, International Monetary Fund, Washington, DC.

Frankel, J. A., and A. K. Rose. 1996. "Currency Crashes in Emerging Markets: An Empirical Treatment." Journal of International Economics 41 (3-4): 351-366.

FSB (Financial Stability Board). 2018a. Implementation and Effects of the G20 Financial Regulatory Reforms. Basel: Financial Stability Board.

. 2018b. Evaluation of the Effects of Financial Regulatory Reforms on Infrastructure Finance. Basel: Financial Stability Board.

2019. "Implementation of G20/FSB financial reforms in other areas: Summary of Key Findings Based on the 2018 FSB Implementation Monitoring Network (IMN) Survey." Financial Stability Board, Basel, Switzerland.

Furman, J., and L. H. Summers. 2019. "Who's Afraid of Budget Deficits? How Washington should End Its Debt Obsession." Foreign Affairs 98: 82-94.

Gaspar, V., J. Ralyea, and E. Ture. 2019. "High Debt Hampers Countries' Response to a Fast-Changing Global Economy." IMFBlog; Insights \& Analysis on Economics \& Finance (blog), April 10.

Gordon, R. J. 2012. "Is U.S. Economic Growth Over? Faltering Innovation Confronts the Six Headwinds." NBER Working Paper 18315, National Bureau of Economic Research, Cambridge.

Gourinchas, P.-O., and M. Obstfeld. 2012. "Stories of the Twentieth Century for the Twenty-first," American Economic Journal: Macroeconomics 4 (1): 226-265.

Ha, J., M. A. Kose, and F. Ohnsorge, eds. 2019. Inflation in Emerging and Developing Economies: Evolution, Drivers and Policies. Washington, DC: World Bank.

Haldane, A. G., A. Penalver, V. Saporta, and H. S. Shin. 2005. "Analytics of Sovereign Debt Restructuring." Journal of International Economics 65 (2): 315-333.

Henry, D. 2010. "Agency Costs, Ownership Structure and Corporate Governance Compliance: A Private Contracting Perspective." Pacific-Basin Finance Journal 18 (1): 24-46.

Holston, K., T. Laubach, and J. C. Williams. 2017. "Measuring the Natural Rate of Interest: International Trends and Determinants." Journal of International Economics 108 
(Supplement 1): S59-S75.

Horn, S., C. M. Reinhart, and C. Trebesch. 2019. "China's Overseas Lending." NBER Working Paper 26050, National Bureau of Economic Research, Cambridge.

Hoshi, T. 2011. "Financial Regulation: Lessons from the Recent Financial Crises." Journal of Economic Literature 49 (1): 120-128.

IIF (Institute of International Finance). 2019. "Voluntary Principles for Debt Transparency." Institute of International Finance, Washington, DC.

IMF (International Monetary Fund). 2011. "Assessing Reserve Adequacy." Report prepared by Monetary and Capital Markets, Research, and Strategy, Policy, and Review Departments, February, International Monetary Fund, Washington, DC.

2018a. Macroeconomic Developments and Prospects in Low-Income Developing Countries. Washington, DC: International Monetary Fund.

2018b. Global Financial Stability Report. A Decade after the Global Financial Crisis: Are We Safer? Washington, DC: International Monetary Fund.

. 2019a. Fiscal Monitor: Curbing Corruption. April. Washington, DC: International Monetary Fund.

- 2019b. Global Financial Stability Report. Lower for Longer. October. Washington, DC: International Monetary Fund.

- 2019c. "Fiscal Transparency Initiative: Integration of Natural Resource Management Issues." IMF Policy Paper, International Monetary Fund, Washington DC.

IRC Taskforce on IMF Issues. 2018. "Strengthening the Global Financial Safety Net: Moving Relations between the IMF and Regional Financing Arrangements Forward." ECB Occasional Paper 207, European Central Bank, Frankfurt.

Jaramillo, L., C. Mulas-Granados, and J. T. Jalles. 2017. "Debt Spikes, Blind Spots, and Financial Stress." International Journal of Finance \& Economics 22 (4): 421-437.

Kaminsky, G. L., and C. M. Reinhart. 2000. "On Crises, Contagion, and Confusion." Journal of International Economics 51 (1): 145-168.

- 2001. "Bank Lending and Contagion: Evidence from the Asian Crisis." In Regional and Global Capital Flows: Macroeconomic Causes and Consequences, edited by T. Ito and A. O. Krueger, 73-99. Chicago: University of Chicago Press.

Kawai, M., R. Newfarmer, and S. L. Schmukler. 2005. "Financial Crises: Nine Lessons from East Asia." Eastern Economic Journal 31 (2): 185-207.

Kemoe, L., and Z. Zhan. 2018. "Fiscal Transparency, Borrowing Costs, and Foreign Holdings of Sovereign Debt." IMF Working Paper 18/189, International Monetary Fund, Washington, DC.

Kilic Celik, S., M. A. Kose, and F. Ohnsorge. 2020. "Subdued Potential Growth: Sources and Remedies." In Growth in a Time of Change: Global and Country Perspective on a New Agenda, edited by H.-W. Kim and Z. Qureshi, 25-74. Washington, DC: Brookings 
Institution.

Kinda, T., M. Mlachila, and R. Ouedraogo. 2016. "Commodity Price Shocks and Financial Sector Fragility." IMF Working Paper 16/12, International Monetary Fund, Washington, DC.

Klomp, J. 2015. "Sovereign Risk and Natural Disasters in Emerging Markets." Emerging Markets Finance and Trade 51 (6): 1326-1341.

Koh, W. C., M. A. Kose, P. Nagle, F. Ohnsorge, and N. Sugawara. 2020. "Debt and Financial Crises." Policy Research Working Paper 9116, World Bank, Washington, DC.

Koh, W. C., and S. Yu. 2019. "Macroeconomic and Financial Policies." In A Decade After the Global Recession: Lessons and Challenges for Emerging and Developing Economies, edited by M. A. Kose and F. Ohnsorge. Washington, DC: World Bank.

Kose, M. A., S. Kurlat, F. Ohnsorge, and N. Sugawara. 2017. "A Cross-Country Database of Fiscal Space." Policy Research Working Paper 8157, World Bank, Washington, DC.

Kose, M. A. H. Matsuoka, U. Panizza, and D. Vorisek. 2019. "Inflation Expectations: Review and Evidence." Policy Research Working Paper 8785, World Bank, Washington, DC.

Kose, M. A., P. Nagle, F. Ohnsorge, and N. Sugawara. 2020. Global Waves of Debt: Causes and Consequences. Washington, DC: World Bank.

Kose, M. A., and F. Ohnsorge, eds. 2019. A Decade Since the Global Recession: Lessons and Challenges for Emerging and Developing Economies. Washington, DC: World Bank.

Kose, M. A, F. Ohnsorge, and N. Sugawara. 2020. "Benefits and Costs of Debt: The Dose Makes the Poison." Policy Research Working Paper, World Bank. Washington, DC.

Kroszner, R. S. 2003. "Sovereign Debt Restructuring." American Economic Review 93 (2): 75-79.

Krugman, P. 2019. "Perspectives on Debt and Deficits." Business Economics 54 (3): 157159.

Laeven, L. 2014. "The Development of Local Capital Markets: Rationale and Challenges." IMF Working Paper 14/234, International Monetary Fund, Washington, DC.

Lee, A., and F. Bachmair. 2019. "A Look Inside the Mind of Debt Managers: A Survey on Contingent Liabilities Risk Management." World Bank Treasury Public Debt Management, World Bank, Washington, DC.

Lee, D., H. Zhang, and C. Nguyen. 2018. "The Economic Impact of Natural Disasters in Pacific Island Countries: Adaptation and Preparedness." IMF Working Paper 18/108, International Monetary Fund, Washington, DC.

Lel, U. 2012. "Currency Hedging and Corporate Governance: A Cross-country Analysis." Journal of Corporate Finance 18 (2): 221-237.

Leroy, A., and G. Grandolini. 2016. Principles for Effective Insolvency and Creditor and Debtor Regimes. Washington, DC: World Bank. 
Lis, E., and C. Nickel. 2010. "The Impact of Extreme Weather Events on Budget Balances." International Tax and Public Finance 17 (4): 378-399.

Maliszewski, W., S. Arslanalp, J. Caparusso, J. Garrido, S. Guo, J. S. Kang, W. R. Lam, T. D. Law, W. Liao, N. Rendak, P. Wingender, J. Yu, and L. Zhang. 2016. "Resolving China's Corporate Debt Problem." IMF Working Paper 16/203, International Monetary Fund, Washington, DC.

Mande, V., Y. K. Park, and M. Son. 2012. Equity or Debt Financing: Does Good Corporate Governance Matter? Corporate Governance: An International Review 20 (2): 195-211.

Mauro, P., and J. Zhou. 2019. "Can We Sleep More Soundly?" Prepared for the Twentieth Jacques Polak Annual Research Conference, November 7-8, Washington, DC.

Mazza, J. 2019. "Is Public Debt a Cheap Lunch?” Bruegel (blog), January 21.

Mbaye, S., M. Moreno-Badia, and K. Chae. 2018. "Bailing Out the People? When Private Debt Becomes Public." IMF Working Paper 18/141, International Monetary Fund, Washington, DC.

Menezes, A. 2014. "Debt Resolution and Business Exit: Insolvency Reform for Credit, Entrepreneurship, and Growth." Viewpoint: Public Policy for the Private Sector 343, World Bank, Washington, DC.

Mishkin, F. 1999. "Global Financial Instability: Framework, Events, Issues." Journal of Economic Perspectives 13 (4): 3-20.

Molnar, M., and J. Lu. 2019. "State-owned Firms Behind China's Corporate Debt." OECD Economics Department Working Paper 1536, Organisation for Economic Cooperation and Development, Paris.

Montes, G. C., J. C. A. Bastos, and A. J. de Oliveira. 2019. "Fiscal Transparency, Government Effectiveness and Government Spending Efficiency: Some International Evidence Based on Panel Data Approach." Economic Modelling 79 (June): 211-225.

Nagle, P. 2020. "Waves of Debt in Emerging and Developing Economies." Policy Research Working Paper, World Bank, Washington, DC.

Nakatani, R. 2019. "A Possible Approach to Fiscal Rules in Small Islands - Incorporating Natural Disasters and Climate Change." IMF Working Paper 19/186, International Monetary Fund, Washington, DC.

Noy, I., and A. Nualsri. 2011. "Fiscal Storms: Public Spending and Revenues in the Aftermath of Natural Disasters." Environment and Development Economics 16 (1): 113128.

Rachel, L., and L. H. Summers. 2019. "On Falling Neutral Real Rates, Fiscal Policy, and the Risk of Secular Stagnation." BPEA Conference Draft, March 7-8, Brookings Institution, Washington, DC.

Reinhart, C. M., and K. S. Rogoff. 2008. "Is the 2007 U.S. Sub-Prime Financial Crisis So Different? An International Historical Comparison." American Economic Review 98 (2): 
339-344.

. 2014. "This Time is Different: A Panoramic View of Eight Centuries of Financial Crises." Annals of Economics and Finance 15 (2): 215-268.

Riedl, B. 2019. "Yes, We Should Fear Budget Deficits." Economics 21 (blog), February 8.

Rodrik, D., and A. Velasco. 2000. "Short-Term Capital Flows." In Annual World Bank Conference on Development Economics 1999, edited by B. Pleskovic and J. E. Stiglitz, 59-90. Washington, DC: World Bank.

Rogoff, K. 2019. "Government Debt is Not A Free Lunch." Project Syndicate, December 6 .

Romer, C. D., and D. H. Romer. 2019. "Fiscal Space and the Aftermath of Financial Crises: How it Matters and Why." NBER Working Paper 25768, National Bureau of Economic Research, Cambridge.

Ruch, F. U. 2019. "Prospects, Risks and Vulnerabilities." In A Decade After the Global Recession: Lessons and Challenges for Emerging and Developing Economies, edited by M. A. Kose and F. Ohnsorge. Washington, DC: World Bank.

Rutledge, V., M. Moore, M. Dobler, W. Bossu, N. Jassaud, and J. Zhou. 2012. "From Bail-Out to Bail-In: Mandatory Debt Restructuring of Systemic Financial Institutions." IMF Staff Discussion Note 2012/03, International Monetary Fund, Washington, DC.

Sachs, J. 1986. "Managing the LDC Debt Crisis." Brookings Papers on Economic Activity 1986 (2): 397-440.

Sahay, R., M. Čihák, P. N’Diaye, A. Barajas, R. Bi, D. Ayala, Y. Gao, A. Kyobe, L. Nguyen, C. Saborowski, K. Svirydzenka, S. R. Yousefi. 2015. "Rethinking Financial Deepening: Stability and Growth in Emerging Markets." IMF Staff Discussion Note 15/08, International Monetary Fund, Washington, DC.

Schaechter, A., T. Kinda, N. T. Budina, and A. Weber. 2012. "Fiscal Rules in Response to the Crisis-Toward the 'Next-Generation' Rules: A New Dataset." IMF Working Paper 12/187, International Monetary Fund, Washington, DC.

Summers, L. H. 2001. "An Analysis of Russia's 1998 Meltdown: Fundamentals and Market Signals. Comments and Discussion." Brookings Papers on Economic Activity 2001 (1): 51-68.

Trebesch, C. 2019. "Resolving Sovereign Debt Crises: The Role of Political Risk." Oxford Economic Papers 71 (2): 421-444.

Ülgentürk, L. 2017. "The Role of Public Debt Managers in Contingent Liability Management." OECD Working Paper on Sovereign Borrowing and Public Debt Management 8, Organisation for Economic Co-operation and Development, Paris.

Van Rijckeghem, C., and B. Weder. 2009. "Political Institutions and Debt Crises." Public Choice 138 (3/4): 387-408. 
van Wijnbergen, S. 1987. "Protectionism and the Debt Crisis." DRD Discussion Paper 266, Development Research Department, World Bank, Washington, DC.

Wang, D., K. Wan, and X. Song. 2018. "Quota Allocation of Coal Overcapacity Reduction Among Provinces in China." Energy Policy 116 (May): 170-181.

Weber, A. 2012. "Stock-Flow Adjustments and Fiscal Transparency: A Cross-Country Comparison." IMF Working Paper 12/39, International Monetary Fund, Washington, DC.

Williams, J. C. 2018. "The Future Fortunes of R-star: Are They Really Rising?" FRBSF Economic Letter 2018-13, Federal Reserve Bank of San Francisco.

World Bank. 2013. Europe and Central Asia: Sovereign Debt Management in Crisis: A Toolkit for Policymakers. Washington, DC: World Bank.

. 2015. Global Economic Prospects Report: Having Fiscal Space and Using It. January. Washington, DC: World Bank.

. 2016. Global Economic Prospects: Spillovers amid Weak Growth. January. Washington, DC: World Bank.

World Bank.

2017a. Global Economic Prospects: A Fragile Recovery. June. Washington, DC:

- 2017b. Tax Revenue Mobilization: Lessons from World Bank Group Support for Tax Reform. Washington, DC: World Bank.

- 2018a. Global Economic Prospects: Broad-Based Upturn, but for How Long? January. Washington, DC: World Bank.

- 2018b. Global Economic Prospects: The Turning of the Tide. June. Washington, DC: World Bank.

2019a. Global Economic Prospects: Heightened Tensions, Subdued Investment. June. Washington, DC: World Bank.

2019b. Global Financial Development Report 2019/2020: Bank Regulation and Supervision a Decade after the Global Financial Crisis. Washington, DC: World Bank.

2020. Global Economic Prospects: Slow Growth, Policy Challenges. January. Washington, DC: World Bank.

World Bank and IMF (International Monetary Fund). 2001. Developing Government Bond Markets: A Handbook. Washington, DC: World Bank.

- 2009a. "Developing a Medium-Term Debt Management Strategy (MTDS): Guidance Note for Country Authorities." World Bank, Washington, DC.

—. 2009b. "Managing Public Debt: Formulating Strategies and Strengthening Institutional Capacity." World Bank, Washington, DC.

- 2014. "Revised Guidelines for Public Debt Management." World Bank, Washington, DC. 
2018. "G-20 Note: Improving Public Debt Recording, Monitoring and Reporting Capacity in Low and Lower Middle-Income Countries: Proposed Reforms." World Bank, Washington, DC.

Wyplosz, C. 2019. "Olivier in Wonderland." VoxEU.org, June 17.

Yu, B., and C. Shen. 2019. "Environmental Regulation and Industrial Capacity Utilization: An Empirical Study of China." Journal of Cleaner Production. Advance online publication. https://doi.org/10.1016/j.jclepro.2019.118986.

Yu, S. 2016. "The Effect of Political Factors on Sovereign Default." Review of Political Economy 28 (3): 397-416. 